\title{
Complexes of germanium(IV) fluoride with phosphane ligands: structural and spectroscopic authentication of germanium(IV) phosphane complexes
}

Martin F. Davis, William Levason, ${ }^{*}$ Gillian Reid and Michael Webster

School of Chemistry, University of Southampton, Southampton, UK SO17

1BJ.E-mail:wxl@soton.ac.uk

Please cite this paper as:

Dalton Transactions, 2008, (17), pp 2261-2269

The publisher's version of this paper is available here:

http://pubs.rsc.org/en/Content/ArticleLanding/2008/DT/b716765b

\footnotetext{
Related articles by Prof William Levason can be found below:

Kathryn George; Andrew L.Hector; William Levason; Gillian Reid; George Sanderson; Michael Webster; Wen-Jian Zhang., (2011), ‘Hypervalent neutral O-donor ligand complexes of silicon tetrafluoride, comparisons with other group 14 tetrafluorides and a search for soft donor ligand complexes' Dalton

Transactions (2011), 40, pp1584-1593. (doi:10.1039/c0dt01115k)

Marek Jura; William Levason; Edmund Petts; Gillian Reid; Michael Webster; Wenjian Zhang, (2010) 'Taking TiF4 complexes to extremes - the first examples with phosphine co-ligands' Dalton Transactions (2010), 39, pp10264-10271. (doi:10.1039/c0dt00747a)

Martin F.Davis; William Levason; Gillian Reid; Michael Webster; Wenjian Zhang, (2008) 'The first examples of germanium tetrafluoride and tin tetrafluoride complexes with soft thioether coordination-synthesis, properties and crystal structures' Dalton Transactions (2008), pp533-538. (doi:10.1039/b713316b).

Martin F. Davis; Maria Clarke; William Levason; Gillian Reid; Michael Webster, (2006) 'Tin(IV) fluoride complexes with tertiary phosphane ligands - a comparison of hard and soft donor ligands' European Journal of Inorganic Chemistry (2006), pp2773-2782. (doi:10.1002/ejic.200600202).
} 


\title{
Complexes of germanium(IV) fluoride with phosphane ligands: structural and spectroscopic authentication of germanium(IV) phosphane complexes $\dagger$
}

\author{
Martin F. Davis, William Levason,* Gillian Reid and Michael Webster
}

\author{
Received 31st October 2007, Accepted 11th February 2008 \\ First published as an Advance Article on the web 19th March 2008 \\ DOI: 10.1039/b716765b
}

\begin{abstract}
The first phosphane complexes of germanium(IV) fluoride, trans- $\left[\mathrm{GeF}_{4}\left(\mathrm{PR}_{3}\right)_{2}\right](\mathrm{R}=\mathrm{Me}$ or $\mathrm{Ph})$ and cis- $\left[\mathrm{GeF}_{4}\right.$ (diphosphane)] (diphosphane $=\mathrm{R}_{2} \mathrm{P}\left(\mathrm{CH}_{2}\right)_{2} \mathrm{PR}, \mathrm{R}=\mathrm{Me}, \mathrm{Et}$, $\mathrm{Ph}$ or $\mathrm{Cy} ; o-\mathrm{C}_{6} \mathrm{H}_{4}\left(\mathrm{PR}_{2}\right)_{2}, \mathrm{R}=$ $\mathrm{Me}$ or $\mathrm{Ph}$ ) have been prepared from $\left[\mathrm{GeF}_{4}(\mathrm{MeCN})_{2}\right]$ and the ligands in dry $\mathrm{CH}_{2} \mathrm{Cl}_{2}$ and characterised by microanalysis, IR, Raman, ${ }^{1} \mathrm{H},{ }^{19} \mathrm{~F}\left\{{ }^{1} \mathrm{H}\right\}$ and ${ }^{31} \mathrm{P}\left\{{ }^{1} \mathrm{H}\right\}$ NMR spectroscopy. The crystal structures of $\left[\mathrm{GeF}_{4}(\right.$ diphosphane) $]$ (diphosphane $=\mathrm{Ph}_{2} \mathrm{P}\left(\mathrm{CH}_{2}\right)_{2} \mathrm{PPh}_{2}$ and $\left.o-\mathrm{C}_{6} \mathrm{H}_{4}\left(\mathrm{PMe}_{2}\right)_{2}\right)$ have been determined and show the expected cis octahedral geometries. In anhydrous $\mathrm{CH}_{2} \mathrm{Cl}_{2}$ solution the complexes are slowly converted into the corresponding phosphane oxide adducts by dry $\mathrm{O}_{2}$. The apparently contradictory literature on the reaction of $\mathrm{GeCl}_{4}$ with phosphanes is clarified. The complexes trans- $\left[\mathrm{GeCl}_{4}\left(\mathrm{AsR}_{3}\right)_{2}\right]$ ( $\mathrm{R}=\mathrm{Me}$ or $\mathrm{Et}$ ) are obtained from $\mathrm{GeCl}_{4}$ and $\mathrm{AsR}_{3}$ either without solvent or in $\mathrm{CH}_{2} \mathrm{Cl}_{2}$, and the structures of trans- $\left[\mathrm{GeCl}_{4}\left(\mathrm{AsEt}_{3}\right)_{2}\right]$ and $\mathrm{Et}_{3} \mathrm{AsCl}_{2}$ determined. Unexpectedly, the complexes of $\mathrm{GeF}_{4}$ with arsane ligands are very unstable and have not been isolated in a pure state. The behaviour of the germanium(IV) halides towards phosphane and arsane ligands are compared with the corresponding silicon(IV) and tin(IV) systems.
\end{abstract}

\section{Introduction}

In marked contrast to the very extensive chemistry with d-block metals, complexes of the p-block metals and metalloids with soft neutral ligands such as phosphanes or arsanes have been relatively little investigated. Whilst a variety of phosphane complexes are known for the heavier halides of $\mathrm{Ga}^{\mathrm{III}}, \mathrm{In}^{\mathrm{III}}, \mathrm{Bi}^{\mathrm{III}}$ and $\mathrm{Sn}^{\mathrm{IV}}$, little is known about other Lewis acids in this block. ${ }^{1-4}$ Complexes of the p-block fluorides with phosphanes are extremely rare, and apart from some very early work on $\mathrm{SiF}_{4},{ }^{1}$ the only examples are from our recent study of $\mathrm{SnF}_{4}$ adducts, ${ }^{5}$ which provided detailed spectroscopic and structural data on a range of complexes including $\left[\mathrm{SnF}_{4}\right.$ (diphosphane)] (diphosphane $=o-\mathrm{C}_{6} \mathrm{H}_{4}\left(\mathrm{PR}_{2}\right)_{2}$, $\mathrm{R}=\mathrm{Me}$ or $\mathrm{Ph} ; \mathrm{R}_{2} \mathrm{P}\left(\mathrm{CH}_{2}\right)_{2} \mathrm{PR}_{2}, \mathrm{R}=\mathrm{Me}, \mathrm{Et}, \mathrm{Cy}$ or $\left.\mathrm{Ph}\right)$ and trans$\left[\mathrm{SnF}_{4}\left(\mathrm{PR}_{3}\right)_{2}\right](\mathrm{R}=\mathrm{Me}$ or $\mathrm{Cy}) .^{5}$ There are no reports of tertiary phosphane complexes of $\mathrm{GeF}_{4}$, and with $\mathrm{GeCl}_{4}$ the reports are few and apparently contradictory. Beattie ${ }^{6}$ and $\mathrm{Ozin}^{7}$ and their coworkers reported the formation of trans- $\left[\mathrm{GeCl}_{4}\left(\mathrm{PMe}_{3}\right)_{2}\right]$ and $\left[\mathrm{GeX}_{4}\left(\mathrm{PMe}_{3}\right)\right](\mathrm{X}=\mathrm{Cl}$ or $\mathrm{Br})$ respectively, by reaction of $\mathrm{GeX}_{4}$ and $\mathrm{PMe}_{3}$ in the absence of a solvent, and used detailed IR and Raman studies to identify the products. In contrast, the reactions of $\mathrm{PR}_{3}\left(\mathrm{R}={ }^{\mathrm{t}} \mathrm{Bu}\right.$ or $\left.{ }^{\mathrm{i}} \mathrm{Pr}\right)$ with $\mathrm{GeX}_{4}$ in benzene gave the redox products $\left[\mathrm{PR}_{3} \mathrm{X}\right]\left[\mathrm{Ge}^{\mathrm{II}} \mathrm{X}_{3}\right] .{ }^{8}$ In a recent study by Godfrey et al., ${ }^{9}$ the reaction of $\mathrm{GeCl}_{4}$ with a wide range of tertiary phosphanes $\left(\mathrm{PR}_{3}\right.$, $\mathrm{R}=\mathrm{Me}, \mathrm{Et},{ }^{\mathrm{n}} \mathrm{Pr},{ }^{\mathrm{n}} \mathrm{Bu}, \mathrm{Cy}$ etc.) in diethyl ether solution was found to give exclusively $\left[\mathrm{PR}_{3} \mathrm{Cl}\right]\left[\mathrm{Ge}^{\mathrm{II}} \mathrm{Cl}_{3}\right]$, identified by microanalysis, ${ }^{31} \mathrm{P}\left\{{ }^{1} \mathrm{H}\right\}$ NMR spectroscopy and by the crystal structure of

School of Chemistry, University of Southampton, Southampton, UK SO17 1BJ.E-mail:wxl@soton.ac.uk

$\dagger$ Electronic supplementary information (ESI) available: Structures (Fig. S1 and S2), and bond lengths and angles (Table $\mathrm{S} 1$ and $\mathrm{S} 2$ ) of $\left[\mathrm{Me}_{2} \mathrm{P}(\mathrm{H})\left(\mathrm{CH}_{2}\right)_{2} \mathrm{P}(\mathrm{H}) \mathrm{Me}_{2}\right]\left[\mathrm{GeCl}_{3}\right]_{2}$ and $\left[\mathrm{Me}_{2} \mathrm{P}(\mathrm{O})\left(\mathrm{CH}_{2}\right)_{2} \mathrm{P}(\mathrm{O}) \mathrm{Me}_{2} \mathrm{H}\right]-$ $\left[\mathrm{GeCl}_{3}\right]$. CCDC reference numbers 665905-665910. For ESI and crystallographic data in CIF or other electronic format see DOI: $10.1039 / \mathrm{b} 716765 \mathrm{~b}$
$\left[\mathrm{P}^{\mathrm{n}} \mathrm{Bu}_{3} \mathrm{Cl}\right]\left[\mathrm{GeCl}_{3}\right]$. Similar redox reactions occur with primary and secondary phosphanes, although the initial products often undergo further reaction with elimination of $\mathrm{HX}$ to form species such as $\mathrm{R}_{2} \mathrm{PGeX}_{3}$ or $\mathrm{RHPGeX}_{3} \cdot{ }^{10}$ However Godfrey et al. ${ }^{9}$ were able to prepare and structurally characterise the first $\mathrm{Ge}^{\mathrm{IV}}$ arsane, trans $-\left[\mathrm{GeCl}_{4}\left(\mathrm{AsMe}_{3}\right)_{2}\right]$. The redox chemistry in the $\mathrm{GeX}_{4}-\mathrm{PR}_{3}$ reactions (at least under some conditions) contrasts with that of the $\mathrm{SnX}_{4}$ systems where simple adduct formation occurs with the majority of phosphanes and diphosphanes. ${ }^{4-7}$ It should be noted however that $\mathrm{P}^{\mathrm{t}} \mathrm{Bu}_{3}$ and $\mathrm{SnX} \mathrm{X}_{4}$ produce $\left[\mathrm{P}^{\mathrm{t}} \mathrm{Bu}_{3} \mathrm{X}\right]\left[\mathrm{SnX} \mathrm{X}_{3}\right] .{ }^{8}$ Here we report the synthesis, structural and spectroscopic characterisation of a series of phosphane complexes of $\mathrm{GeF}_{4}$, further studies into the $\mathrm{GeCl}_{4}$ and $\mathrm{GeBr}_{4}$ reactions, and also studies of complexes of $\mathrm{GeX}_{4}$ with arsane ligands.

\section{Results and discussion}

\section{Germanium(IV) phosphanes}

Our previous studies have shown that towards hard $\mathrm{N}$ - or $\mathrm{O}-$ donor ligands $\mathrm{GeF}_{4}$ is a much stronger Lewis acid than $\mathrm{GeCl}_{4}$ or $\mathrm{GeBr}_{4}{ }^{11}$ The reaction of $\left[\mathrm{GeF}_{4}(\mathrm{MeCN})_{2}\right]^{11}$ with two mol. equivalents of $\mathrm{PMe}_{3}$ in anhydrous $\mathrm{CH}_{2} \mathrm{Cl}_{2}$ gave $\left[\mathrm{GeF}_{4}\left(\mathrm{PMe}_{3}\right)_{2}\right]$ (Scheme 1) as a white, moisture sensitive powder, only slightly soluble in chlorocarbons. The ${ }^{1} \mathrm{H}$ NMR spectrum in $\mathrm{CD}_{2} \mathrm{Cl}_{2}$ solution contained a single doublet at $\delta=1.46\left({ }^{2} J_{\mathrm{PH}}=12 \mathrm{~Hz}\right)$, the ${ }^{19} \mathrm{~F}\left\{{ }^{1} \mathrm{H}\right\}$ NMR spectrum is a $1: 2: 1$ triplet at $295 \mathrm{~K}$, and was unchanged on cooling, showing only the trans isomer was present in detectable amounts. As expected, the ${ }^{31} \mathrm{P}\left\{{ }^{1} \mathrm{H}\right\}$ NMR spectrum is a quintet at $\delta=-12.4\left({ }^{2} J_{\mathrm{PF}}=196 \mathrm{~Hz}\right)$. The corresponding reaction using $\mathrm{PPh}_{3}$ gave white trans-[GeF $\left.4\left(\mathrm{PPh}_{3}\right)_{2}\right]($ Table 1$)$ which was easily soluble in chlorocarbons, but extensively dissociated at room temperature in solution. The ${ }^{19} \mathrm{~F}\left\{{ }^{1} \mathrm{H}\right\}$ and ${ }^{31} \mathrm{P}\left\{{ }^{1} \mathrm{H}\right\}$ NMR data were recorded at $210 \mathrm{~K}$ and show the expected multiplets, but 

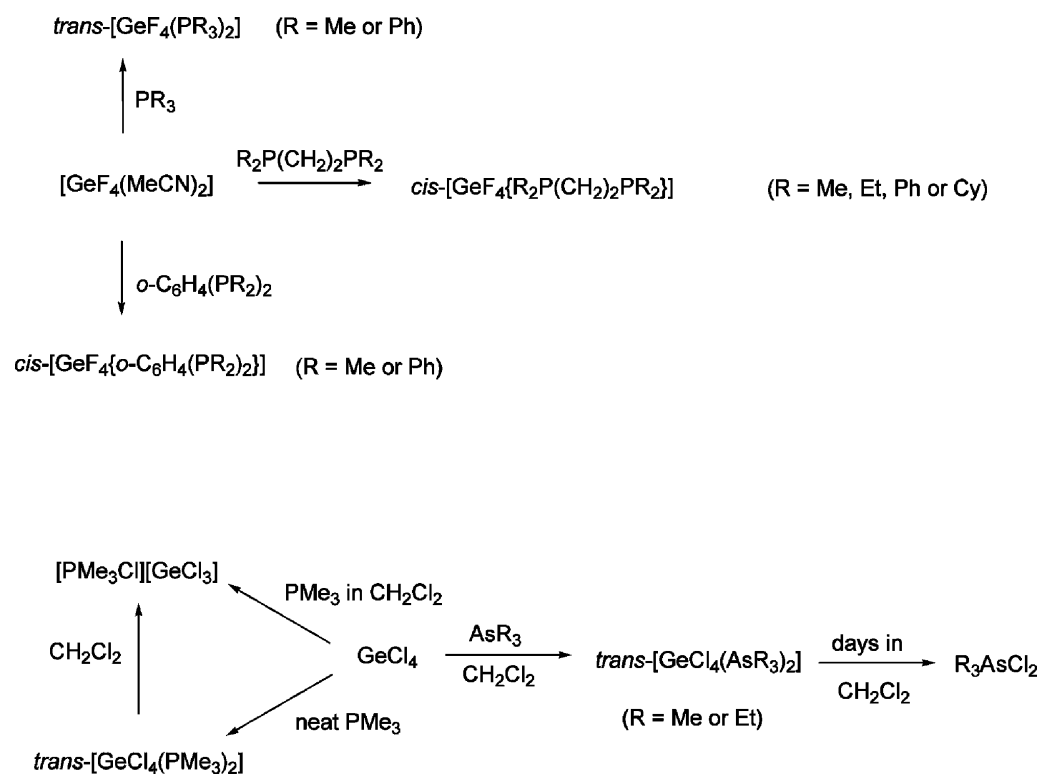

Scheme 1

on warming to $>240 \mathrm{~K}$ the resonances are lost. In view of the easy chlorination of phosphanes by $\mathrm{GeCl}_{4}$ (vide infra), the reaction of $\left[\mathrm{GeF}_{4}(\mathrm{MeCN})_{2}\right]$ with excess molten $\mathrm{PPh}_{3}$ was also carried out, which constitutes more forcing conditions, but examination of the products by ${ }^{31} \mathrm{P}\left\{{ }^{1} \mathrm{H}\right\}$ and ${ }^{19} \mathrm{~F}\left\{{ }^{1} \mathrm{H}\right\}$ NMR spectroscopy revealed only trans- $\left[\mathrm{GeF}_{4}\left(\mathrm{PPh}_{3}\right)_{2}\right]$, traces of $\left[\mathrm{GeF}_{4}\left(\mathrm{OPPh}_{3}\right)_{2}\right]^{11}$ and excess $\mathrm{PPh}_{3}$, and there is no evidence for fluorination of the ligand (to $\left.\mathrm{Ph}_{3} \mathrm{PF}_{2}\right)$. Attempts to isolate trans- $\left[\mathrm{GeF}_{4}\left(\mathrm{PCy}_{3}\right)_{2}\right]$ were unsuccessful, the products obtained were extremely moisture sensitive and NMR studies suggested a mixture of species was present.

The reactions of $\left[\mathrm{GeF}_{4}\left(\mathrm{MeCN}_{2}\right]\right.$ with the diphosphanes $\mathrm{R}_{2} \mathrm{P}\left(\mathrm{CH}_{2}\right)_{2} \mathrm{PR}_{2}(\mathrm{R}=\mathrm{Me}$, Et, $\mathrm{Ph}$ or $\mathrm{Cy})$ and $o-\mathrm{C}_{6} \mathrm{H}_{4}\left(\mathrm{PR}_{2}\right)_{2}$ $(\mathrm{R}=\mathrm{Me}$ or $\mathrm{Ph})$ in anhydrous $\mathrm{CH}_{2} \mathrm{Cl}_{2}$ were undertaken with the aim of obtaining cis isomers and in the expectation that chelation would produce more stable complexes. These readily gave $c i s-\left[\mathrm{GeF}_{4}\right.$ (diphosphane)] as white powders, which can be handled briefly in air with no detectable decomposition. Like the tin analogues, the solids tenaciously retain chlorinated solvents (evident in the ${ }^{1} \mathrm{H}$ NMR spectra). The complexes exhibit several strong, overlapping $v(\mathrm{GeF})$ vibrations in their IR spectra in the range $620-560 \mathrm{~cm}^{-1}$ (theory for a cis- $\mathrm{MF}_{4} \mathrm{P}_{2}$ is four IR active stretches: $\left.2 a_{1}+b_{1}+b_{2}\right)$ which may be compared with the $t_{1 u}$ mode in $\left[\mathrm{GeF}_{6}\right]^{2-}$ at $600 \mathrm{~cm}^{-1}$. $^{12}\left[\mathrm{GeF}_{4}\left\{\mathrm{Me}_{2} \mathrm{P}\left(\mathrm{CH}_{2}\right)_{2} \mathrm{PMe}_{2}\right\}\right]$ is only slightly soluble in $\mathrm{CH}_{2} \mathrm{Cl}_{2}$ but the other complexes dissolve easily in chlorocarbons. The ${ }^{1} \mathrm{H}$ NMR spectra in $\mathrm{CD}_{2} \mathrm{Cl}_{2}$ or $\mathrm{CDCl}_{3}$ solution at $295 \mathrm{~K}$ are simple, showing only coordinated diphosphane ligands present. At ambient temperatures both the ${ }^{19} \mathrm{~F}\left\{{ }^{1} \mathrm{H}\right\}$ and ${ }^{31} \mathrm{P}\left\{{ }^{1} \mathrm{H}\right\}$ NMR spectra are broad lines with ill-defined or unresolved couplings, indicative of reversible dissociation or chelate ring-opening on the appropriate NMR time-scales. On moderate cooling of the solutions (273-243 K depending on the ligand present), the resonances sharpen and show the coupling patterns expected for cis-octahedral complexes (Table 1). ${ }^{5}$ The ${ }^{31} \mathrm{P}\left\{{ }^{1} \mathrm{H}\right\}$ spectra are 12 line patterns $(\mathrm{d}, \mathrm{d}, \mathrm{t})$ and the ${ }^{19} \mathrm{~F}\left\{{ }^{1} \mathrm{H}\right\}$ spectra show two resonances; a $\mathrm{t}, \mathrm{t}$ for the two axial fluorines and a d,d,t for the fluorines trans to phosphorus. The chemical shifts and coupling constants are shown in Table 1. Notably the spectra show no other species present in significant amounts and are unchanged after the solutions have been allowed to stand for several hours. The ${ }^{31} \mathrm{P}\left\{{ }^{1} \mathrm{H}\right\}$ chemical shifts are very similar to those observed in the analogous $\left[\mathrm{SnF}_{4}(\right.$ diphosphane $\left.)\right]$ complexes, ${ }^{5}$ and as in those cases the coordination shifts $\Delta\left(\Delta=\delta_{\text {complex }}-\delta_{\text {ligand }}\right)$ are irregular, although generally the stronger $\sigma$-donor ligands produce high frequency

Table 1 Selected NMR data for $\mathrm{GeF}_{4}$ complexes $^{a}$

\begin{tabular}{lcrlc}
\hline Compound & $\delta^{31} \mathrm{P}\left\{{ }^{1} \mathrm{H}\right\}^{b}$ & $\Delta^{c}$ & $\delta{ }^{19} \mathrm{~F}\left\{{ }^{1} \mathrm{H}\right\}$ & ${ }^{2} J\left({ }^{31} \mathrm{P}-{ }^{19} \mathrm{~F}\right) / \mathrm{Hz}$ \\
\hline$\left[\mathrm{GeF}_{4}\left\{o-\mathrm{C}_{6} \mathrm{H}_{4}\left(\mathrm{PMe}_{2}\right)_{2}\right\}\right]$ & $-31.8(t, d, d)$ & 23 & $-97.2(\mathrm{t}, \mathrm{t}),-126.0(\mathrm{~d}, \mathrm{~d}, \mathrm{t})$ & $77,135,155$ \\
{$\left[\mathrm{GeF}_{4}\left\{o-\mathrm{C}_{6} \mathrm{H}_{4}\left(\mathrm{PPh}_{2}\right)_{2}\right\}\right]$} & $-17.1(t, d, d)$ & -4 & $-81.9(\mathrm{t}, \mathrm{t}),-121.9(\mathrm{~d}, \mathrm{~d}, \mathrm{t})$ & $64,110,129$ \\
{$\left[\mathrm{GeF}_{4}\left\{\mathrm{Et}_{2} \mathrm{P}\left(\mathrm{CH}_{2}\right)_{2} \mathrm{PEt}_{2}\right\}\right]$} & $-9.2(t, d, d)$ & 9 & $-91.9(\mathrm{t}, \mathrm{t}),-113.6(\mathrm{~d}, \mathrm{~d}, \mathrm{t})$ & $66,131,136$ \\
{$\left[\mathrm{GeF}_{4}\left\{\mathrm{Me}_{2} \mathrm{P}\left(\mathrm{CH}_{2}\right)_{2} \mathrm{PMe}_{2}\right\}\right]$} & $-24.6(t, d, d)$ & 23 & $-96.2(\mathrm{t}, \mathrm{t}),-121.2(\mathrm{~d}, \mathrm{~d}, \mathrm{t})$ & $80,135,149$ \\
{$\left[\mathrm{GeF}_{4}\left\{\mathrm{Ph}_{2} \mathrm{P}\left(\mathrm{CH}_{2}\right)_{2} \mathrm{PPh}_{2}\right\}\right]$} & $-17.1(t, d, d)$ & -4 & $-73.7(\mathrm{t}, \mathrm{t}),-110.3(\mathrm{~d}, \mathrm{~d}, \mathrm{t})$ & $64,119,151$ \\
{$\left[\mathrm{GeF}_{4}\left\{\mathrm{Cy}_{2} \mathrm{P}\left(\mathrm{CH}_{2}\right)_{2} \mathrm{PCy}_{2}\right\}\right]$} & $-8.7(t, d, d)$ & -11 & $-81.2(\mathrm{t}, \mathrm{t}),-103.1(\mathrm{~d}, \mathrm{~d}, \mathrm{t})$ & $60,121,122$ \\
trans $-\left[\mathrm{GeF}_{4}\left(\mathrm{PMe}_{3}\right)_{2}\right]$ & $-12.4(q)$ & 50 & $-96.9(\mathrm{t})$ & 196 \\
trans $-\left[\mathrm{GeF}_{4}\left(\mathrm{PPh}_{3}\right)_{2}\right]^{d}$ & $2.8(q)$ & 8 & $-70.6(\mathrm{t})$ & 180
\end{tabular}

${ }^{a}$ In $\mathrm{CH}_{2} \mathrm{Cl}_{2}-10 \% \mathrm{CDCl}_{3}$. Spectra were typically recorded at $240 \mathrm{~K}$ to resolve couplings (see text). ${ }^{b}$ Ligand chemical shifts are: $o-\mathrm{C}_{6} \mathrm{H}_{4}\left(\mathrm{PMe}_{2}\right)_{2}-55$; $o$ - $\mathrm{C}_{6} \mathrm{H}_{4}\left(\mathrm{PPh}_{2}\right)_{2}-13 ; \mathrm{Ph}_{2} \mathrm{P}\left(\mathrm{CH}_{2}\right)_{2} \mathrm{PPh}_{2}-13 ; \mathrm{Et}_{2} \mathrm{P}\left(\mathrm{CH}_{2}\right)_{2} \mathrm{PEt}_{2}-18 ; \mathrm{Me}_{2} \mathrm{P}\left(\mathrm{CH}_{2}\right)_{2} \mathrm{PMe}_{2}-48 ; \mathrm{Cy}_{2} \mathrm{P}\left(\mathrm{CH}_{2}\right)_{2} \mathrm{PCy}_{2}+2 ; \mathrm{PMe}_{3}-62 ; \mathrm{PPh}_{3}-6 \mathrm{ppm}^{c} \mathrm{Coordination}$ $\operatorname{shift}\left(\Delta=\delta_{\text {complex }}-\delta_{\text {ligand }}\right){ }^{d}$ At $190 \mathrm{~K}$. Resonances disappear $>240 \mathrm{~K}$. 
coordination shifts and the weaker donor aryl-diphosphanes low frequency shifts. Only $\left[\mathrm{GeF}_{4}\left\{\mathrm{Cy}_{2} \mathrm{P}\left(\mathrm{CH}_{2}\right)_{2} \mathrm{PCy}_{2}\right\}\right]$ does not conform to this pattern, exhibiting a coordination shift of -11 , despite being a strong $\sigma$-donor. It is likely that steric factors from this bulky ligand on the small germanium centre are a major contributor here. These erratic coordination shifts are seen in phosphane complexes of $\mathrm{Sn}^{\mathrm{IV} 4}$ and $\mathrm{Ga}^{\mathrm{III}},{ }^{13}$ but the cause is presently unclear. The ${ }^{19} \mathrm{~F}\left\{{ }^{1} \mathrm{H}\right\}$ chemical shifts are higher frequency than those observed in the $\left[\mathrm{SnF}_{4}(\right.$ diphosphane) $]$ analogues ${ }^{5}$ and the ${ }^{2} J_{\mathrm{FF}}$ and ${ }^{2} J_{\mathrm{PF}}$ couplings are larger in the germanium systems. Similar ${ }^{2} J_{\mathrm{FF}}$ values $(50-60 \mathrm{~Hz})$ are found in cis- $\left[\mathrm{GeF}_{4}\left(\mathrm{OPR}_{3}\right)_{2}\right]^{11}$ and in $\left[\mathrm{GeF}_{4}(\mathrm{~L}-\mathrm{L})\right]\left(\mathrm{L}-\mathrm{L}=2,2^{\prime}\right.$-bipyridyl, 1,10-phenanthroline, $\left.\mathrm{Me}_{2} \mathrm{~N}\left(\mathrm{CH}_{2}\right)_{2} \mathrm{NMe}_{2}\right){ }_{1}^{14}$ although rather larger values $(70-80 \mathrm{~Hz})$ are seen in $\left[\mathrm{GeF}_{4}\left\{\mathrm{RS}\left(\mathrm{CH}_{2}\right)_{2} \mathrm{SR}\right\}\right] .{ }^{15}$

Confirmation of the $\left[\mathrm{GeF}_{4}(\right.$ diphosphane)] constitution was provided by X-ray crystal structures of two examples, with the diphosphanes $o-\mathrm{C}_{6} \mathrm{H}_{4}\left(\mathrm{PMe}_{2}\right)_{2}$ and $\mathrm{Ph}_{2} \mathrm{P}\left(\mathrm{CH}_{2}\right)_{2} \mathrm{PPh}_{2}$. The structure of the former is shown in Fig. 1, and Table 2 contains selected bond lengths and angles. The germanium environment is approximately octahedral with the angles $\mathrm{F}-\mathrm{Ge}-\mathrm{F}$ slightly greater than $90^{\circ}, \mathrm{F}-\mathrm{Ge}-\mathrm{P}$ slightly less than $90^{\circ}$, and $\mathrm{P}-\mathrm{Ge}-\mathrm{P} 85.61(4)^{\circ}$. As observed in $\mathrm{GeF}_{4}$ complexes with N- or O-donor ligands, ${ }^{11,14} \mathrm{Ge}-$ $\mathrm{F}_{\text {trans } \mathrm{F}}(1.809(2), 1.815(2) \AA)$ are longer than $\mathrm{Ge}-\mathrm{F}_{\text {trans } \mathrm{P}}(1.765(2)$, 1.772(2) ̊). Similar patterns of bond lengths and angles are found in the structure of $\left[\mathrm{GeF}_{4}\left\{\mathrm{Ph}_{2} \mathrm{P}\left(\mathrm{CH}_{2}\right)_{2} \mathrm{PPh}_{2}\right\}\right]$ (Fig. 2, Table 3) although the Ge-P bonds are slightly longer in the complex of the aryl-diphosphane, possibly due to its weaker $\sigma$-donation.

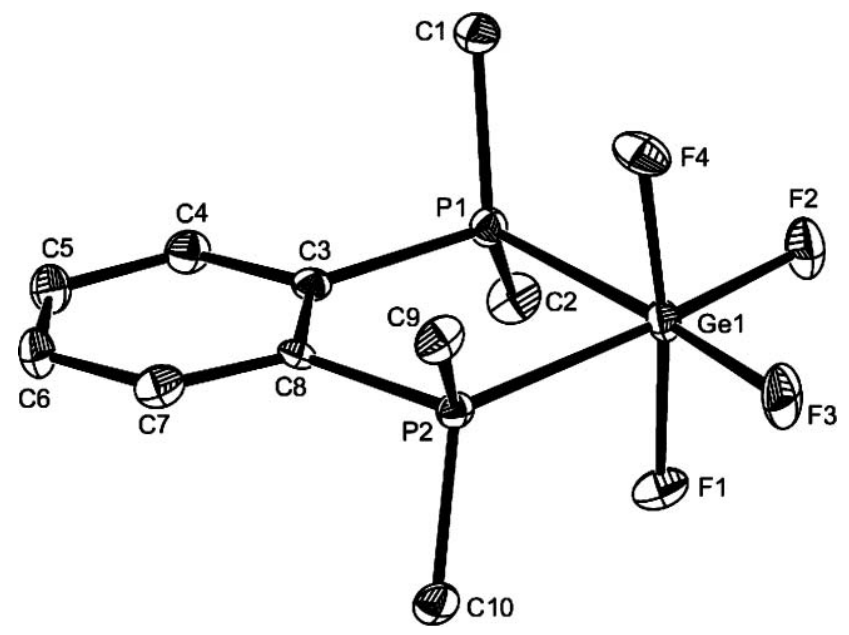

Fig. 1 Structure of $\left[\mathrm{GeF}_{4}\left\{o-\mathrm{C}_{6} \mathrm{H}_{4}\left(\mathrm{PMe}_{2}\right)_{2}\right\}\right]$ with the atom numbering scheme adopted. $\mathrm{H}$ atoms are omitted for clarity and displacement ellipsoids are shown at the $50 \%$ probability level.

Table 2 Selected bond lengths $(\AA)$ and angles $\left({ }^{\circ}\right)$ for $\left[\mathrm{GeF}_{4}\{o\right.$ $\left.\left.\mathrm{C}_{6} \mathrm{H}_{4}\left(\mathrm{PMe}_{2}\right)_{2}\right\}\right]$

\begin{tabular}{llll}
\hline Ge1-F1 & $1.815(2)$ & Ge1-F3 & $1.772(2)$ \\
Ge1-F2 & $1.765(2)$ & Ge1-F4 & $1.809(2)$ \\
Ge1-P1 & $2.4273(12)$ & Ge1-P2 & $2.4273(11)$ \\
& & & \\
F2-Ge1-F3 & $93.91(10)$ & F2-Ge1-F4 & $92.49(12)$ \\
F3-Ge1-F4 & $93.18(12)$ & F2-Ge1-F1 & $92.76(12)$ \\
F3-Ge1-F1 & $91.56(12)$ & F2-Ge1-P1 & $89.80(8)$ \\
F4-Ge1-P1 & $87.65(9)$ & F1-Ge1-P1 & $87.26(8)$ \\
F3-Ge1-P2 & $90.70(9)$ & F4-Ge1-P2 & $86.77(9)$ \\
F1-Ge1-P2 & $87.59(8)$ & P1-Ge1-P2 & $85.61(4)$ \\
\hline
\end{tabular}

Table 3 Selected bond lengths $(\AA)$ and angles $\left({ }^{\circ}\right)$ for $\left[\mathrm{GeF}_{4}{ }^{-}\right.$ $\left.\left\{\mathrm{Ph}_{2} \mathrm{P}\left(\mathrm{CH}_{2}\right)_{2} \mathrm{PPh}_{2}\right\}\right]$

\begin{tabular}{llll}
\hline Ge1-F1 & $1.7987(14)$ & Ge1-F3 & $1.7731(14)$ \\
Ge1-F2 & $1.7829(13)$ & Ge1-F4 & $1.7692(14)$ \\
Ge1-P1 & $2.4636(7)$ & Ge1-P2 & $2.4822(7)$ \\
& & & \\
F4-Ge1-F3 & $93.21(7)$ & F4-Ge1-F2 & $93.44(6)$ \\
F3-Ge1-F2 & $93.44(7)$ & F3-Ge1-F1 & $93.02(7)$ \\
F4-Ge1-F1 & $92.71(7)$ & F2-Ge1-P1 & $89.28(4)$ \\
F4-Ge1-P2 & $90.18(5)$ & F1-Ge1-P1 & $83.94(5)$ \\
F2-Ge1-P2 & $88.08(5)$ & F1-Ge1-P2 & $85.08(5)$ \\
F3-Ge1-P1 & $92.44(5)$ & P1-Ge1-P2 & $84.08(2)$ \\
\hline
\end{tabular}

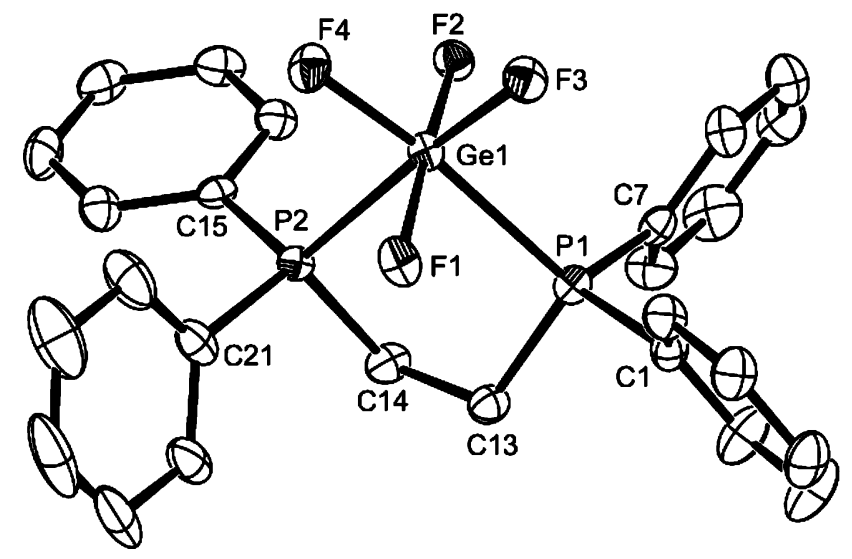

Fig. 2 Structure of $\left[\mathrm{GeF}_{4}\left\{\mathrm{Ph}_{2} \mathrm{P}\left(\mathrm{CH}_{2}\right)_{2} \mathrm{PPh}_{2}\right\}\right]$ with the atom numbering scheme adopted. $\mathrm{H}$ atoms are omitted for clarity and displacement ellipsoids are shown at the $50 \%$ probability level. Only the ipso $\mathrm{C}$ atom labels are shown and $\mathrm{C}$ atoms are numbered sequentially round the ring starting at the label shown.

Studies of the $\mathrm{SnX}_{4}-\mathrm{PR}_{3}$ systems ${ }^{5}$ showed that in the presence of air, the corresponding phosphane oxide complexes, $\left[\mathrm{SnX}_{4}\left(\mathrm{OPR}_{3}\right)_{2}\right],{ }^{16}$ form, and we have shown ${ }^{17}$ using ${ }^{18} \mathrm{O}_{2}$, that the source of the oxygen is dioxygen rather than water. Using $\mathrm{SnI}_{4}$ the reaction provides a convenient catalytic route to phosphane oxides. ${ }^{17}$ A solution of $\left[\mathrm{GeF}_{4}\left(\mathrm{PPh}_{3}\right)_{2}\right]$ in $\mathrm{CH}_{2} \mathrm{Cl}_{2}$ exposed to dry air, deposited crystals identified by an X-ray structure to be trans$\left[\mathrm{GeF}_{4}\left(\mathrm{OPPh}_{3}\right)_{2}\right]{ }^{11}$ and since $\mathrm{PPh}_{3}$ is air stable in solution, this demonstrates that the reaction was promoted by the germanium complex. In view of the generation of $\left[\mathrm{PR}_{3} \mathrm{X}\right]\left[\mathrm{GeX}_{3}\right]$ in the cases of $\mathrm{X}=\mathrm{Cl}$ or $\mathrm{Br}$, which could hydrolyse to $\mathrm{OPR}_{3}$, it was important to establish the source of the oxygen atoms

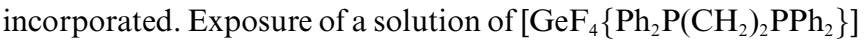
in $\mathrm{CH}_{2} \mathrm{Cl}_{2}$ to dry ${ }^{18} \mathrm{O}_{2}$ resulted in the slow formation of the diphosphane dioxide complex (monitored in situ by ${ }^{31} \mathrm{P}\left\{{ }^{1} \mathrm{H}\right\}$ NMR spectroscopy). After the reaction appeared complete the complex was decomposed by treatment with aqueous $\mathrm{NaOH}$, and separation of the organic layer, drying and evaporation produced a white solid. The EI mass spectrum of this solid showed a base peak at $m / z=433$ corresponding to $\left[\mathrm{Ph}_{2} \mathrm{P}\left({ }^{18} \mathrm{O}\right)\left(\mathrm{CH}_{2}\right)_{2} \mathrm{P}\left({ }^{18} \mathrm{O}\right) \mathrm{PPh}_{2}-\right.$ $\mathrm{H}]^{+}$, and the IR spectrum showed $v(\mathrm{PO})$ at $1153 \mathrm{~cm}^{-1}$. The $\mathrm{Ph}_{2} \mathrm{P}\left({ }^{16} \mathrm{O}\right)\left(\mathrm{CH}_{2}\right)_{2} \mathrm{P}\left({ }^{16} \mathrm{O}\right) \mathrm{PPh}_{2}$ exhibits $v(\mathrm{PO})$ at $1177 \mathrm{~cm}^{-1}$, and the simple diatomic oscillator model predicts the effect of ${ }^{18} \mathrm{O}$ substitution will lower this vibration to $1133 \mathrm{~cm}^{-1}$. Coupling with the $v(\mathrm{PC})$ mode at $\sim 1120 \mathrm{~cm}^{-1}$ probably causes the higher frequency observed experimentally. ${ }^{17}$ Thus, like $\mathrm{SnX}_{4},{ }^{5,17} \mathrm{GeF}_{4}$ 
promotes air/dioxygen oxidation of phosphanes, although the reaction is considerably slower with germanium.

\section{$\mathrm{GeX}_{4}-\mathrm{PMe}_{3}(\mathrm{X}=\mathrm{Cl}$ or $\mathrm{Br})$ systems}

Following the successful characterisation of the phosphane adducts of $\mathrm{GeF}_{4}$, we re-examined the $\mathrm{GeCl}_{4}-\mathrm{PMe}_{3}$ reaction in an attempt to elucidate the apparently contradictory literature, ${ }^{6-9}$ and found that the reports from Beattie ${ }^{6}$ and Godfrey ${ }^{9}$ and coworkers are both valid, and that the species formed are extremely dependent upon the conditions. We distilled $\mathrm{GeCl}_{4}$ onto neat $\mathrm{PMe}_{3}$ at $77 \mathrm{~K}$ and allowed the mixture to thaw slowly. On melting, a vigorous reaction occurred which was moderated by judicious cooling, resulting in formation of a white powder. The Raman spectrum of this product (Fig. 3, top) was in excellent agreement with that reported by Beattie with a very strong feature at $267 \mathrm{~cm}^{-1}$ assigned as the $\mathrm{a}_{1 \mathrm{~g}}$ vibration of trans$\left[\mathrm{GeCl}_{4}\left(\mathrm{PMe}_{3}\right)_{2}\right]$ (lit., $\left.{ }^{6} 268 \mathrm{~cm}^{-1}\right)$ - compare also the values of the corresponding vibration in the crystallographically characterised trans-[ $\left[\mathrm{GeCl}_{4}\left(\mathrm{AsR}_{3}\right)_{2}\right]$ (vide infra). The sample was then dissolved in rigorously dried $\mathrm{CH}_{2} \mathrm{Cl}_{2}$ and the mixture immediately pumped to dryness. The Raman spectrum of this sample showed the features of the initial spectrum and some new bands in the region $>350 \mathrm{~cm}^{-1}$. The sample was redissolved in $\mathrm{CH}_{2} \mathrm{Cl}_{2}$, allowed to stand for $3 \mathrm{~h}$ and then taken to dryness. The Raman spectrum of this sample (Fig. 3, bottom) showed loss of the $267 \mathrm{~cm}^{-1}$
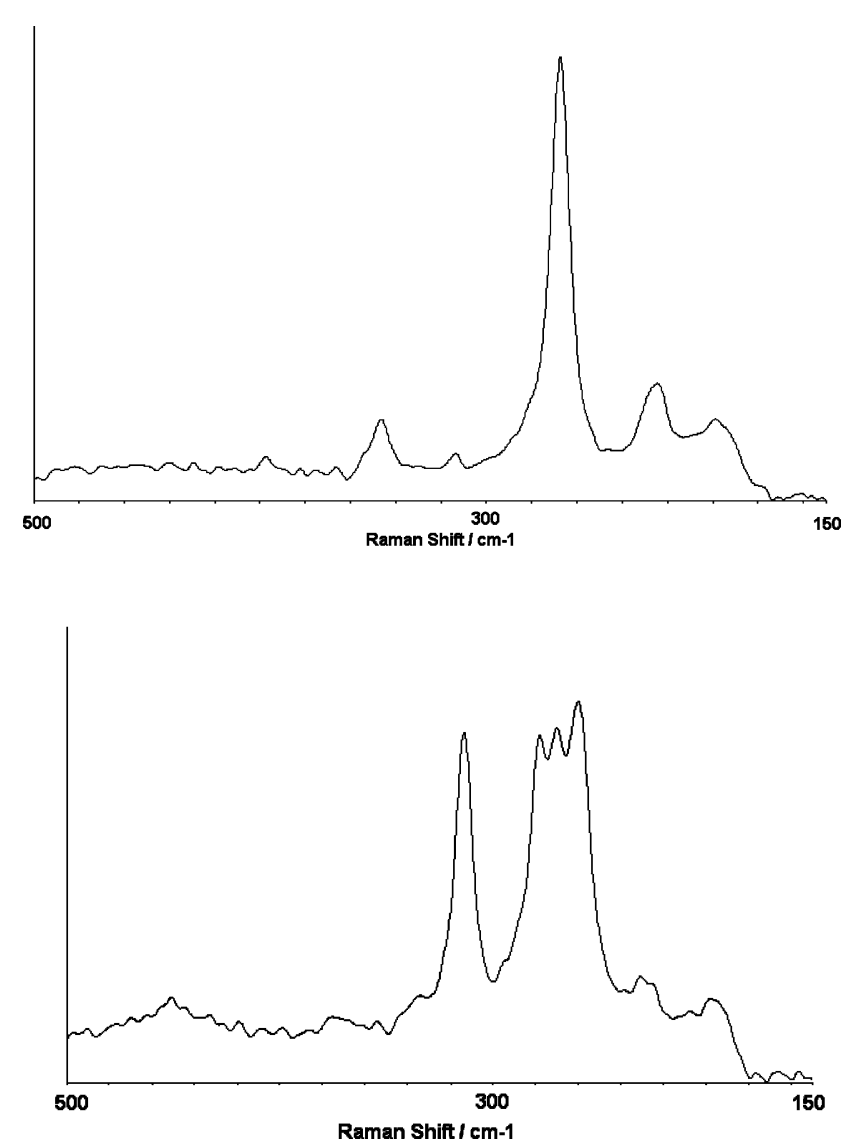

Fig. 3 Raman spectrum of $\left[\mathrm{GeCl}_{4}\left(\mathrm{PMe}_{3}\right)_{2}\right]$ (above) and of $\left[\mathrm{PMe}_{3} \mathrm{Cl}\right]\left[\mathrm{GeCl}_{3}\right]$ (below). From comparison of the intensities in the ligand modes (not shown) the features in the upper spectrum are $\sim 10$ times more intense than those in the lower. feature, but new medium intensity bands at 314 and $260 \mathrm{~cm}^{-1}$ which correspond to $\left[\mathrm{GeCl}_{3}\right]^{-}\left(\left[\mathrm{NBu}_{4}\right]\left[\mathrm{GeCl}_{3}\right]\right.$ has features at $320,255 \mathrm{~cm}^{-1}$ ). The reactions can also be monitored by NMR spectroscopy. The initial solid, dissolved in $\mathrm{CH}_{2} \mathrm{Cl}_{2}$ at $273 \mathrm{~K}$ and immediately cooled to $200 \mathrm{~K}$, does not show a ${ }^{31} \mathrm{P}\left\{{ }^{1} \mathrm{H}\right\}$ NMR resonance from the initial complex, but on standing a new feature at $\delta=+92$ attributablet to $\left[\mathrm{PMe}_{3} \mathrm{Cl}\right]^{+}$appeared. The absence of a phosphorus resonance for the $\mathrm{Ge}^{\mathrm{IV}}$ complex is consistent with extensive dissociation/fast exchange even at low temperatures. This explanation is supported by the ${ }^{1} \mathrm{H}$ NMR spectrum of trans-[ $\left[\mathrm{GeCl}_{4}\left(\mathrm{PMe}_{3}\right)_{2}\right]$ obtained immediately after dissolution in $\mathrm{CDCl}_{3}$, which shows a doublet at $\delta=2.75,{ }^{2} J_{\mathrm{PH}}=$ $13.5 \mathrm{~Hz}$ (assigned to $\left.\left[\mathrm{PMe}_{3} \mathrm{Cl}\right]^{+}\right)$and a doublet at $\delta=1.8,{ }^{2} J_{\mathrm{PH}}=$ $13 \mathrm{~Hz}$ for the $\mathrm{Ge}^{\mathrm{IV}}$ complex. Trace hydrolysis of the solution also produces $\left[\mathrm{PMe}_{3} \mathrm{H}\right]\left[\mathrm{GeCl}_{3}\right], \delta\left({ }^{31} \mathrm{P}\right)=-4.9$, and from such a hydrolysed sample we obtained crystals identified by their unit cell as $\left[\mathrm{PMe}_{3} \mathrm{H}\right]\left[\mathrm{GeCl}_{3}\right] .{ }^{19}$ Hence, as described by Beattie and Ozin, ${ }^{6}$ the reaction of $\mathrm{GeCl}_{4}$ with $\mathrm{PMe}_{3}$ in the absence of a solvent does indeed give trans-[ $\left[\mathrm{GeCl}_{4}\left(\mathrm{PMe}_{3}\right)_{2}\right]$, but this rapidly rearranges in solution in chlorocarbons or ethers to $\left[\mathrm{PMe}_{3} \mathrm{Cl}\right]\left[\mathrm{GeCl}_{3}\right]$, and the latter is obtained when the reaction is performed in solution (Scheme 1). ${ }^{8,9}$ The recrystallisation of $\left[\mathrm{GeCl}_{4}\left(\mathrm{PMe}_{3}\right)_{2}\right]$ from hot $\mathrm{GeCl}_{4}$ was reported to give $\left[\mathrm{GeCl}_{4}\left(\mathrm{PMe}_{3}\right)\right]$, believed to be an axially-substituted trigonal bipyramid molecule, ${ }^{7}$ however the reported Raman spectrum is very similar to that of $\left[\mathrm{PMe}_{3} \mathrm{Cl}\right]\left[\mathrm{GeCl}_{3}\right]$ and we suggest the latter is the correct formulation. We also reacted $\mathrm{GeBr}_{4}$ and $\mathrm{PMe}_{3}$ in the absence of solvent and obtained a cream powder with a Raman spectrum identical to that reported ${ }^{7}$ for $\left[\mathrm{GeBr}_{4}\left(\mathrm{PMe}_{3}\right)\right]$. In this case also, the strongest features in the low energy region correspond to $\left[\mathrm{GeBr}_{3}\right]^{-}$, and on dissolution in dry $\mathrm{CH}_{2} \mathrm{Cl}_{2}$ the ${ }^{31} \mathrm{P}\left\{{ }^{1} \mathrm{H}\right\}$ NMR resonance is found at $\delta=+68$, probably corresponding to $\left[\mathrm{PMe}_{3} \mathrm{Br}\right]^{+}$.

We have not examined other tertiary phosphanes, but is seems likely that similar reactions would occur with initial formation of a tetrachlorogermanium(IV) adduct which then (especially in solution) undergoes a redox reaction to form $\left[\mathrm{PR}_{3} \mathrm{Cl}\right]\left[\mathrm{GeCl}_{3}\right]$ - in some cases the rearrangement may be so rapid that the Ge(IV) species is only a transient intermediate. $\mathrm{The} \mathrm{GeBr}_{4}-\mathrm{PMe}_{3}$ reaction appears to give $\left[\mathrm{PMe}_{3} \mathrm{Br}\right]\left[\mathrm{GeBr}_{3}\right]$ without any evidence that a $\mathrm{Ge}(\mathrm{IV})$ complex is isolable. In contrast, the silicon(IV) and tin(IV) complexes are stable (although very moisture sensitive) and trans$\left[\mathrm{SiCl}_{4}\left(\mathrm{PMe}_{3}\right)_{2}\right]^{20}$ and several $\mathrm{SnX}_{4}$-phosphane complexes ${ }^{4,5}$ have been authenticated by X-ray crystal structures.

In the hope of obtaining more stable Ge(IV) complexes, we examined the reaction of the bidentate $\mathrm{Me}_{2} \mathrm{P}\left(\mathrm{CH}_{2}\right)_{2} \mathrm{PMe}_{2}$ with $\mathrm{GeCl}_{4}$ under a variety of reaction conditions (mixed in the absence of solvent, in solution in $\mathrm{CH}_{2} \mathrm{Cl}_{2}$ or $\mathrm{Et}_{2} \mathrm{O}$, at room or low temperatures) and monitored reactions by in situ ${ }^{31} \mathrm{P}\left\{{ }^{1} \mathrm{H}\right\}$ NMR spectroscopy. The reactions are very sensitive to the conditions, and resonances due to mono- and di-chlorinated and -protonated phosphane groups could be identified, the relative amounts varying with conditions and reaction times, and with trace hydrolysis in some samples. We were unable to unequivocally identify resonances in the ${ }^{1} \mathrm{H}$ or ${ }^{31} \mathrm{P}\left\{{ }^{1} \mathrm{H}\right\}$ NMR spectra due

\$ The observed ${ }^{31} \mathrm{P}$ chemical shift of " $\left[\mathrm{PMe}_{3} \mathrm{Cl}\right]^{+}$" seems to vary with solvent, concentration and anion, probably due to subtle speciation involving $\left[\mathrm{PMe}_{3} \mathrm{Cl}\right]^{+}, \mathrm{Me}_{3} \mathrm{PCl}_{2}$ and $\mathrm{Me}_{3} \mathrm{PCl} \cdots \mathrm{Cl}$ forms (see reference 18 and references therein). 
to $\left[\mathrm{GeCl}_{4}\left\{\mathrm{Me}_{2} \mathrm{P}\left(\mathrm{CH}_{2}\right)_{2} \mathrm{PMe}_{2}\right\}\right]$, although this may be due to fast dissociative ligand exchange even at low temperature. The only species identified crystallographically were $\left[\mathrm{GeCl}_{3}\right]^{-}$salts with $\left[\mathrm{Me}_{2} \mathrm{PH}\left(\mathrm{CH}_{2}\right)_{2} \mathrm{PHMe}_{2}\right]^{2+}$ or $\left[\mathrm{Me}_{2} \mathrm{P}(\mathrm{O})\left(\mathrm{CH}_{2}\right)_{2} \mathrm{P}(\mathrm{O}) \mathrm{Me}_{2} \mathrm{H}\right]^{+}$ deposited over several days or weeks (see $\mathrm{ESI} \dagger$ ). We conclude that the reactions of the diphosphane with $\mathrm{GeCl}_{4}$ are similar to those with $\mathrm{PMe}_{3}$, with the trichlorogermanate(II) as the final product.

The reason for the easier reduction of $\mathrm{GeX}_{4}(\mathrm{X}=\mathrm{Cl}$ or $\mathrm{Br})$ by phosphanes compared with $\mathrm{SnX}_{4}$ or $\mathrm{SiX}_{4}$ (or the relative instability of the $\left.\left[\mathrm{GeX}_{4}\left(\mathrm{PR}_{3}\right)_{2}\right]\right)$, may be an example in germanium chemistry of the lower stability of the element of period 4 in the group oxidation state compared with analogues in periods 3 or 5. This effect is well known for $\mathrm{As}^{\mathrm{V}}, \mathrm{Se}^{\mathrm{VI}}$ and $\mathrm{Br}^{\mathrm{VII}}$ and is usually rationalised as the result of increased nuclear charge from the $3 \mathrm{~d}$ transition metals not completely balanced by screening from the $3 \mathrm{~d}$ electrons. ${ }^{21}$

\section{Germanium(IV) arsanes}

The reactions of $\left[\mathrm{GeF}_{4}(\mathrm{MeCN})_{2}\right]$ with $o-\mathrm{C}_{6} \mathrm{H}_{4}\left(\mathrm{AsMe}_{2}\right)_{2}$ or $\mathrm{AsMe}_{3}$ in $\mathrm{CH}_{2} \mathrm{Cl}_{2}$ afford unstable, very moisture sensitive white solids, with IR and Raman spectra which show the presence of the appropriate ligand and $\mathrm{Ge}-\mathrm{F}$ bonds and no $\mathrm{MeCN}$. The ${ }^{1} \mathrm{H}$ NMR spectra in $\mathrm{CD}_{2} \mathrm{Cl}_{2}$ show the arsane resonances shifted to high frequency from those of the "free" ligands. None of the samples showed ${ }^{19} \mathrm{~F}\left\{{ }^{1} \mathrm{H}\right\}$ NMR resonances at room temperature, but on cooling to $<220 \mathrm{~K}$ two triplets of equal intensity appear in regions typical of "cis" $-\mathrm{GeF}_{4}$ units. However, microanalytical data obtained from different samples were always significantly low in $\mathrm{C}$ and $\mathrm{H}$ compared with expectation for $\left[\mathrm{GeF}_{4}\{o-\right.$ $\left.\mathrm{C}_{6} \mathrm{H}_{4}\left(\mathrm{AsMe}_{2}\right)_{2}\right\}$ ], and the microanalytical data on the $\mathrm{GeF}_{4}-$ $\mathrm{AsR}_{3}$ systems reproducibly approximate to $1: 1$ compounds. In the latter case, the spectroscopic data (see Experimental section) would be consistent with either a cis disubstituted octahedron or an equatorially substituted trigonal bipyramid. We have been unable to obtain crystals of these complexes for X-ray studies and their precise nature remains unclear. There appeared to be no complex formation between $\mathrm{GeF}_{4}$ and the weaker $\sigma$ donor $\mathrm{Ph}_{2} \mathrm{As}\left(\mathrm{CH}_{2}\right)_{2} \mathrm{AsPh}_{2}$. Thus, although $\mathrm{GeF}_{4}$ appears to form adducts with some arsane ligands, these appear to be extensively dissociated in solution and far less stable than the phosphane analogues - a pattern also observed in the $\mathrm{SnF}_{4}$ systems. ${ }^{5}$ Isolation of pure complexes in the tin systems is complicated by the " $\mathrm{SnF}_{4}$ " formed on dissociation, precipitating as polymeric $\left[\mathrm{SnF}_{4}\right]_{n}$, but in the germanium systems dissociation simply forms $\mathrm{GeF}_{4}$ monomer, and the instability is therefore a direct result of the low affinity of the hard germanium Lewis acid for the soft arsenic centre.

The reaction of $\mathrm{GeCl}_{4}$ with $\mathrm{AsMe}_{3}$ in $\mathrm{CH}_{2} \mathrm{Cl}_{2}$ or $\mathrm{Et}_{2} \mathrm{O}$ at ambient temperatures, produced colourless crystals of trans$\left[\mathrm{GeCl}_{4}\left(\mathrm{AsMe}_{3}\right)_{2}\right]$ which were identified by comparison of their unit cell with the literature data. ${ }^{9} \mathrm{~A}$ similar reaction using $\mathrm{AsEt}_{3}$ in $\mathrm{CH}_{2} \mathrm{Cl}_{2}$ followed by rapid isolation of the product gave white trans- $\left[\mathrm{GeCl}_{4}\left(\mathrm{AsEt}_{3}\right)_{2}\right]$ and crystals obtained from $\mathrm{CH}_{2} \mathrm{Cl}_{2}$ showed a similar structure (Fig. 4, Table 4). The centrosymmetric molecule has $\mathrm{Ge}-\mathrm{As}=2.490(1) \AA$, slightly longer than that in trans$\left[\mathrm{GeCl}_{4}\left(\mathrm{AsMe}_{3}\right)_{2}\right](2.472(1) \AA)$. If the solution was allowed to stand for a few days very pale yellow crystals were deposited which were identified by their IR and Raman spectra as $\mathrm{Et}_{3} \mathrm{AsCl}_{2}{ }^{22}$ The identity was confirmed by the crystal structure (Fig. 5,
Table 4 Selected bond lengths (̊̊) and angles $\left({ }^{\circ}\right)$ for trans$\left[\mathrm{GeCl}_{4}\left(\mathrm{AsEt}_{3}\right)_{2}\right]$

\begin{tabular}{llll}
\hline Ge1-Cl1 & $2.3296(19)$ & Ge1-Cl2 & $2.3233(19)$ \\
Ge1-As1 & $2.4904(9)$ & As1-C & $1.930(8)-1.944(8)$ \\
& & & \\
Cl2-Ge1-Cl1 & $90.67(7)$ & Ge1-As1-C & $110.9(2)-116.0(2)$ \\
Cl2-Ge1-As1 & $87.03(5)$ & C-As1-C & $105.1(4)-106.4(4)$ \\
Cl1-Ge1-As1 & $88.29(5)$ & & \\
\hline
\end{tabular}

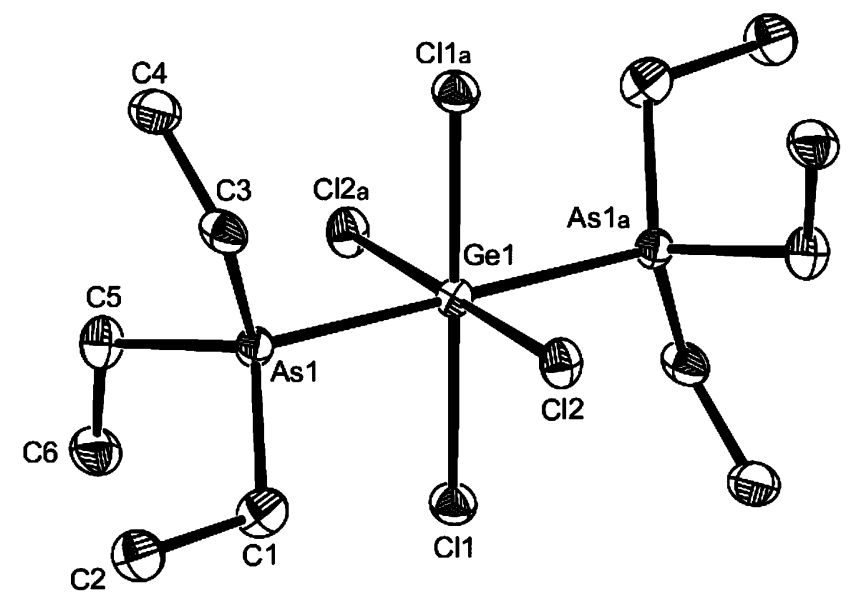

Fig. 4 Structure of the centrosymmetric trans $-\left[\mathrm{GeCl}_{4}\left(\mathrm{AsEt}_{3}\right)_{2}\right]$ with the atom numbering scheme adopted. $\mathrm{H}$ atoms are omitted for clarity and displacement ellipsoids are shown at the $50 \%$ probability level. Symmetry operation: $\mathrm{a}=-x,-y,-z$.

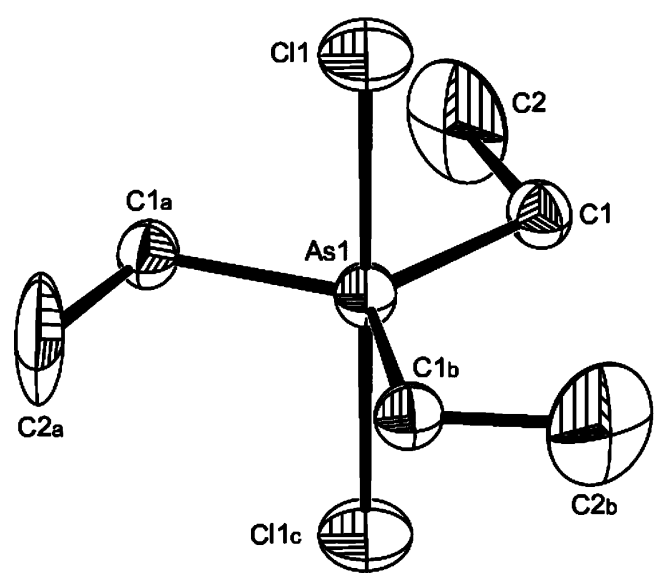

Fig. 5 Structure of $\mathrm{Et}_{3} \mathrm{AsCl}_{2}$ with the atom numbering scheme adopted. $\mathrm{H}$ atoms are omitted for clarity and displacement ellipsoids are shown at the $50 \%$ probability level. There are two molecules in the asymmetric unit. The second has the same symmetry and similar bond lengths and angles (see Table 5). Symmetry operations: $\mathrm{a}=1-y, x-y, z ; \mathrm{b}=1-x+y$, $1-x, z ; \mathrm{c}=x, y,-z$.

Table 5) which showed the expected trigonal bipyramid geometry with similar $\mathrm{As}-\mathrm{Cl}$ and $\mathrm{As}-\mathrm{C}$ bond lengths to those in related compounds such as $\mathrm{Me}_{3} \mathrm{AsCl}_{2}$ and $\mathrm{Cy}_{3} \mathrm{AsCl}_{2}{ }^{23,24}$ The trans$\left[\mathrm{GeCl}_{4}\left(\mathrm{AsR}_{3}\right)_{2}\right]$ were also made by reaction of $\mathrm{GeCl}_{4}$ with the ligands in the absence of a solvent ( $c f$. the $\mathrm{GeCl}_{4}-\mathrm{PMe}_{3}$ reactions vide supra) and had identical Raman spectra to samples obtained using $\mathrm{CH}_{2} \mathrm{Cl}_{2}$ as solvent.

The Raman spectra obtained from solid trans- $\left[\mathrm{GeCl}_{4}\left(\mathrm{AsR}_{3}\right)_{2}\right]$ $\left(\mathrm{R}=\mathrm{Me}\right.$ or Et) show very strong bands at $266 \mathrm{~cm}^{-1}(\mathrm{Me})$ or 
Table 5 Selected bond lengths $(\AA)$ and angles $\left({ }^{\circ}\right)$ for $\mathrm{Et}_{3} \mathrm{AsCl}_{2}$

\begin{tabular}{llll}
\hline As1-Cl1 & $2.382(4)$ & As2-Cl2 & $2.362(4)$ \\
As1-C1 & $1.927(6)$ & As2-C3 & $1.918(7)$ \\
C1-C2 & $1.604(13)$ & C3-C4 & $1.637(12)$ \\
& & & \\
C-As1-C & 120.0 & C-As2-C & 120.0 \\
C-As1-Cl & 90.0 & C-As2-Cl & 90.0 \\
As1-C1-C2 & $105.4(5)$ & As2-C3-C4 & $105.9(6)$ \\
\hline
\end{tabular}

$259 \mathrm{~cm}^{-1}$ (Et) which are assigned as the $\mathrm{a}_{1 \mathrm{~g}}$ modes, but in Nujol mulls (the solids dissolve in the Nujol), the strongest band in each far-IR spectrum is at $456 \mathrm{~cm}^{-1}$ which corresponds to the $\mathrm{t}_{2}$ mode of tetrahedral $\mathrm{GeCl}_{4},{ }^{25}$ showing that they are substantially dissociated even in this medium. The ${ }^{1} \mathrm{H}$ NMR spectra of both complexes are little different to those of the ligands and do not change even on cooling to $190 \mathrm{~K}$, again consistent with extensive dissociation. Upon standing, the solution of trans- $\left[\mathrm{GeCl}_{4}\left(\mathrm{AsEt}_{3}\right)_{2}\right]$ in $\mathrm{CD}_{2} \mathrm{Cl}_{2}$ develops new features at $\delta=1.60\left(\mathrm{t},{ }^{3} J_{\mathrm{HH}}=7.5\right.$ $\mathrm{Hz}$ ) and 3.06 (q), which correspond to $\mathrm{Et}_{3} \mathrm{AsCl}_{2},{ }^{22}$ confirming the slow decomposition. We confirm the previous report ${ }^{9}$ that no reaction occurs between $\mathrm{GeCl}_{4}$ and $\mathrm{AsPh}_{3}$ in either $\mathrm{CH}_{2} \mathrm{Cl}_{2}$ or $\mathrm{Et}_{2} \mathrm{O}$ at ambient temperatures. No reaction occurred with $\mathrm{GeCl}_{4}$ and the diarsane $\mathrm{Ph}_{2} \mathrm{As}\left(\mathrm{CH}_{2}\right)_{2} \mathrm{AsPh}_{2}$, or (very surprisingly) with $o-\mathrm{C}_{6} \mathrm{H}_{4}\left(\mathrm{AsMe}_{2}\right)_{2}$, which suggests that the stereochemistry at germanium also plays a role (i.e. cis isomers are even less favoured than the trans and the normally expected greater stability of chelate complexes is not found here). The reaction of $\mathrm{GeBr}_{4}$ and $\mathrm{AsEt}_{3}$ in the absence of solvent gave a clear viscous yellow liquid with strong bands in the Raman spectrum at 311, 267, 240 and $205 \mathrm{~cm}^{-1}$ which do not correspond with tetrahedral $\mathrm{GeBr}_{4}\left(328,234 \mathrm{~cm}^{-1}\right)$ or to $\mathrm{Et}_{3} \mathrm{AsBr}_{2},{ }^{22}$ and when dissolved in $\mathrm{CD}_{2} \mathrm{Cl}_{2}$ the ${ }^{1} \mathrm{H} \mathrm{NMR}$ spectrum is little different to that of $\mathrm{AsEt}_{3}$. This suggests that the oil may be trans-[ $\left.\mathrm{GeBr}_{4}\left(\mathrm{AsEt}_{3}\right)_{2}\right]$, again extensively dissociated in solution; extrapolation from the chloride suggests the Raman active $\mathrm{a}_{1 \mathrm{~g}} \mathrm{Ge}-\mathrm{Br}$ vibration will be $\sim 180 \mathrm{~cm}^{-1}$, below the limit of the instrument.

These results show that weak adducts form between $\mathrm{GeCl}_{4}$ and $\mathrm{AsR}_{3}(\mathrm{R}=$ alkyl), but these are highly dissociated in solution, and slowly convert into $\mathrm{R}_{3} \mathrm{AsCl}_{2}$. The slower reduction by $\mathrm{AsR}_{3}$ than by $\mathrm{PR}_{3}$ reflects the relatively weaker reducing power of the arsanes.

\section{Conclusions}

The work has resulted in characterisation of the first phosphane adducts of $\mathrm{GeF}_{4}$ and has shown that while $\mathrm{GeCl}_{4}$ forms (unstable) complexes with some arsanes (but not others), these slowly convert into $\mathrm{R}_{3} \mathrm{AsCl}_{2}$. With phosphanes the reduction to $\mathrm{Ge}^{\mathrm{II}}$ is usually rapid and $\left[\mathrm{GeCl}_{4}\left(\mathrm{PR}_{3}\right)_{2}\right]$ complexes can only be obtained in the absence of solvents. The stability of Lewis acid-base complexes depends upon two major factors - the strength of the donoracceptor bond and the energy needed to reorganise the tetrahedral $\mathrm{GeX}_{4}$ unit into the four-coordinate fragment of the octahedron. The latter is constant for fixed $\mathrm{X}$, and thus the relative affinity for $\mathrm{PR}_{3}$ vs. $\mathrm{AsR}_{3}$ which is $\mathrm{GeF}_{4}>\mathrm{GeCl}_{4}$ for the phosphanes, but appears to be reversed for the arsane compounds, must mainly reflect the difference in orbital energies and donor atom 'softness' between $\mathrm{P}$ and As. The reduction of $\mathrm{Ge}^{\mathrm{IV}}$ to $\mathrm{Ge}^{\mathrm{II}}$ is not evident in the fluoride systems, but is favoured for the $\mathrm{GeCl}_{4}$ (and $\mathrm{GeBr}_{4}$ ) reactions. This contrasts with the chemistry of $\operatorname{SnX}_{4}(X=F, C l$,
$\mathrm{Br}$ or I) all of which form phosphane adducts, although again the affinity of $\mathrm{SnF}_{4}$ for arsanes is much less than for phosphanes. The chemistry observed with $\mathrm{GeX}_{4}$ also seems to differ from the limited data reported for the $\mathrm{SiX}_{4}$ systems, but we reserve detailed comparisons here until much more complete data are available. Studies are underway on the silicon tetrahalide complexes.

\section{Experimental}

$\mathrm{GeF}_{4}$ was obtained from Aldrich and used as received. $\mathrm{GeCl}_{4}$ (Aldrich) was distilled from a mixture of $\mathrm{CaCl}_{2}-\mathrm{Na}_{2} \mathrm{CO}_{3}$, which removes traces of water and $\mathrm{HCl}$. $\mathrm{MeCN}$ and $\mathrm{CH}_{2} \mathrm{Cl}_{2}$ were dried by distillation from $\mathrm{CaH}_{2}$, and diethyl ether from sodium benzophenone ketyl. Ligands were obtained from Aldrich or Strem: $\mathrm{PMe}_{3}, \mathrm{PPh}_{3}, \mathrm{PCy}_{3}, \mathrm{AsMe}_{3}, \mathrm{AsEt}_{3}, \mathrm{Me}_{2} \mathrm{P}\left(\mathrm{CH}_{2}\right)_{2} \mathrm{PMe}_{2}$, $\mathrm{Et}_{2} \mathrm{P}\left(\mathrm{CH}_{2}\right)_{2} \mathrm{PEt}_{2}, \mathrm{Cy}_{2} \mathrm{P}\left(\mathrm{CH}_{2}\right)_{2} \mathrm{PCy}_{2}$, or were made by literature methods: $o-\mathrm{C}_{6} \mathrm{H}_{4}\left(\mathrm{PPh}_{2}\right)_{2}, \mathrm{Ph}_{2} \mathrm{P}\left(\mathrm{CH}_{2}\right)_{2} \mathrm{PPh}_{2}, o-\mathrm{C}_{6} \mathrm{H}_{4}\left(\mathrm{PMe}_{2}\right)_{2}, o$ $\mathrm{C}_{6} \mathrm{H}_{4}\left(\mathrm{AsMe}_{2}\right)_{2} .{ }^{26-29}$ All reactions were conducted using Schlenk, vacuum line and glove-box techniques and under a dry dinitrogen atmosphere. IR spectra were recorded from Nujol mulls on a Perkin Elmer PE 983G spectrometer, Raman spectra using a Perkin Elmer FT Raman 2000R with a Nd:YAG laser. ${ }^{1} \mathrm{H}$ NMR spectra were from $\mathrm{CDCl}_{3}$ or $\mathrm{CD}_{2} \mathrm{Cl}_{2}$ solutions on a Bruker $\mathrm{AV} 300$, ${ }^{19} \mathrm{~F}\left\{{ }^{1} \mathrm{H}\right\}$ and ${ }^{31} \mathrm{P}\left\{{ }^{1} \mathrm{H}\right\}$ NMR spectra on a Bruker DPX400 and referenced to $\mathrm{CFCl}_{3}$ and $85 \% \mathrm{H}_{3} \mathrm{PO}_{4}$ respectively. Microanalytical measurements on new complexes were performed by the microanalytical service at Strathclyde University. $\left[\mathrm{GeF}_{4}(\mathrm{MeCN})_{2}\right]$ was made as described. ${ }^{11}$

\section{$\left[\mathrm{GeF}_{4}\left\{o-\mathrm{C}_{6} \mathrm{H}_{4}\left(\mathrm{PMe}_{2}\right)_{2}\right\}\right]$}

$\left[\mathrm{GeF}_{4}(\mathrm{MeCN})_{2}\right](0.23 \mathrm{~g}, 1.0 \mathrm{mmol})$ was dissolved in $\mathrm{CH}_{2} \mathrm{Cl}_{2}$ $(10 \mathrm{~mL})$ and $o-\mathrm{C}_{6} \mathrm{H}_{4}\left(\mathrm{PMe}_{2}\right)_{2}(0.198 \mathrm{~g}, 1.0 \mathrm{mmol})$ added dropwise; the mixture was stirred for $4 \mathrm{~h}$ at ambient temperatures. Most of the solvent was removed in vacuo and the white powder produced was filtered off and dried in vacuo. Yield $0.32 \mathrm{~g}, 92 \%$. Required for $\mathrm{C}_{10} \mathrm{H}_{16} \mathrm{~F}_{4} \mathrm{GeP}_{2}$ (346.8): C, 34.6; H, 4.7. Found: C, 34.9; H, 4.9\%. ${ }^{1} \mathrm{H}$ NMR $\left(300 \mathrm{MHz}, \mathrm{CDCl}_{3}, 295 \mathrm{~K}\right): \delta=1.81\left(\mathrm{t},{ }^{2} J+{ }^{5} J_{\mathrm{PH}}=\right.$ $4.5 \mathrm{~Hz}, 12 \mathrm{H}, \mathrm{Me}), 7.73-7.83\left(\mathrm{~m}, 4 \mathrm{H}, \mathrm{C}_{6} \mathrm{H}_{4}\right.$ ). IR (Nujol): 607(br), $580(\mathrm{sh}), 567(\mathrm{br}) v(\mathrm{GeF}) \mathrm{cm}^{-1}$.

\section{$\left[\mathrm{GeF}_{4}\left\{\mathbf{P h}_{2} \mathbf{P}\left(\mathrm{CH}_{2}\right)_{2} \mathbf{P P h}_{2}\right\}\right]$}

$\left[\mathrm{GeF}_{4}(\mathrm{MeCN})_{2}\right](0.23 \mathrm{~g}, 1.0 \mathrm{mmol})$ was dissolved in $\mathrm{CH}_{2} \mathrm{Cl}_{2}$ (10 mL), $\mathrm{Ph}_{2} \mathrm{P}\left(\mathrm{CH}_{2}\right)_{2} \mathrm{PPh}_{2}(0.40 \mathrm{~g}, 1.0 \mathrm{mmol})$ in $\mathrm{CH}_{2} \mathrm{Cl}_{2}(5 \mathrm{~mL})$ was added and the mixture stirred for $3 \mathrm{~h}$. Most of the solvent was removed in vacuo and the white precipitate was washed with hexane $(10 \mathrm{~mL})$, filtered off and dried in vacuo. Yield $0.37 \mathrm{~g}, 68 \%$. Required for $\mathrm{C}_{26} \mathrm{H}_{24} \mathrm{~F}_{4} \mathrm{GeP}_{2}$ (547.0): C, 57.1; H, 4.4. Found: C, 56.2; H, 4.5\%. ${ }^{1} \mathrm{H}$ NMR (300 MHz, $\left.\mathrm{CDCl}_{3}, 298 \mathrm{~K}\right): \delta=2.71(\mathrm{~s}$, br, H, $\mathrm{CH}_{2}$ ), 7.79-7.38 (m, 5H, Ph). IR (Nujol): 603(s), 586(br) $v(\mathrm{GeF}) \mathrm{cm}^{-1}$.

\section{$\left[\mathrm{GeF}_{4}\left\{\boldsymbol{o}-\mathrm{C}_{6} \mathrm{H}_{4}\left(\mathrm{PPh}_{2}\right)_{2}\right\}\right]$}

$\left[\mathrm{GeF}_{4}(\mathrm{MeCN})_{2}\right](0.23 \mathrm{~g}, 1.0 \mathrm{mmol})$ and $o-\mathrm{C}_{6} \mathrm{H}_{4}\left(\mathrm{PPh}_{2}\right)_{2}(0.45 \mathrm{~g}$, $1.0 \mathrm{mmol})$ were weighed out and $\mathrm{CH}_{2} \mathrm{Cl}_{2}(10 \mathrm{~mL})$ added, the solution was stirred for $4 \mathrm{~h}$, during which the solution began to turn cloudy and a white precipitate formed. The precipitate was filtered off and dried in vacuo. Yield $0.25 \mathrm{~g}, 42 \%$. Required for 
$\mathrm{C}_{30} \mathrm{H}_{24} \mathrm{~F}_{4} \mathrm{GeP}_{2} \cdot \frac{1}{3} \mathrm{CH}_{2} \mathrm{Cl}_{2}$ (623.4): C, 58.5; H, 4.0. Found: C, 58.7; $\mathrm{H}, 3.8 \% .{ }^{1} \mathrm{H}$ NMR $\left(300 \mathrm{MHz}, \mathrm{CDCl}_{3}, 298 \mathrm{~K}\right): \delta=7.2-7.65(\mathrm{~m}$, $\mathrm{Ph}$ ). IR (Nujol): 619(s), 607(vs, br) $v(\mathrm{GeF}) \mathrm{cm}^{-1}$.

\section{$\left[\mathrm{GeF}_{4}\left\{\mathrm{Me}_{2} \mathrm{P}\left(\mathrm{CH}_{2}\right)_{2} \mathrm{PMe}_{2}\right\}\right]$}

$\mathrm{Me}_{2} \mathrm{P}\left(\mathrm{CH}_{2}\right)_{2} \mathrm{PMe}_{2}(0.15 \mathrm{~g}, 1.0 \mathrm{mmol})$ was added dropwise to a solution of $\left[\mathrm{GeF}_{4}(\mathrm{MeCN})_{2}\right](0.23 \mathrm{~g}, 1.0 \mathrm{mmol})$ in $\mathrm{CH}_{2} \mathrm{Cl}_{2}(10 \mathrm{~mL})$; the mixture was stirred overnight at room temperature. A white precipitate was filtered off and dried in vacuo. Yield $0.29 \mathrm{~g}$, 97\%. Required for $\mathrm{C}_{6} \mathrm{H}_{16} \mathrm{~F}_{4} \mathrm{GeP}_{2} \cdot \frac{1}{2} \mathrm{CH}_{2} \mathrm{Cl}_{2}$ (341.2): C, 22.9; $\mathrm{H}, 5.0$. Found: C, 22.6; H, 5.2\%. ${ }^{1} \mathrm{H}$ NMR (300 MHz, $\mathrm{CDCl}_{3}, 295 \mathrm{~K}$ ): $\delta=1.39$ (m, 3H, Me), 2.05 (m, 2H, $\mathrm{CH}_{2}$ ). IR (Nujol): 565(vbr) $v(\mathrm{GeF}) \mathrm{cm}^{-1}$.

\section{$\left[\mathrm{GeF}_{4}\left\{\mathrm{Et}_{2} \mathbf{P}\left(\mathrm{CH}_{2}\right)_{2} \mathrm{PEt}_{2}\right\}\right]$}

$\mathrm{Et}_{2} \mathrm{P}\left(\mathrm{CH}_{2}\right)_{2} \mathrm{PEt}_{2}(0.206 \mathrm{~g}, 1.0 \mathrm{mmol})$ was added dropwise to a solution of $\left[\mathrm{GeF}_{4}(\mathrm{MeCN})_{2}\right](0.23 \mathrm{~g}, 1.0 \mathrm{mmol})$ in $\mathrm{CH}_{2} \mathrm{Cl}_{2}(10 \mathrm{~mL})$; the mixture was stirred for $4 \mathrm{~h}$. Most of the solvent was removed in vacuo, the solid filtered off and dried in vacuo. Yield $0.29 \mathrm{~g}$, $82 \%$. Required for $\mathrm{C}_{10} \mathrm{H}_{24} \mathrm{~F}_{4} \mathrm{GeP}_{2} \cdot \frac{1}{2} \mathrm{CH}_{2} \mathrm{Cl}_{2}$ (397.3): $\mathrm{C}, 31.7 ; \mathrm{H}, 6.3$. Found: C, 31.2; H, 7.0\%. ${ }^{1} \mathrm{H}$ NMR (300 MHz, $\mathrm{CDCl}_{3}, 295 \mathrm{~K}$ ): $\delta=1.25(\mathrm{~m}, 3 \mathrm{H}, \mathrm{Me}), 1.97\left(\mathrm{~m}, 2 \mathrm{H}, \mathrm{CH}_{2}\right), 2.06\left(\mathrm{~m}, 2 \mathrm{H}, \mathrm{CH}_{2}\right) . \mathrm{IR}$ (Nujol): 605(sh), 577(vbr), 560(sh) $v(\mathrm{GeF}) \mathrm{cm}^{-1}$.

\section{$\left[\mathrm{GeF}_{4}\left\{\mathrm{Cy}_{2} \mathrm{P}\left(\mathrm{CH}_{2}\right)_{2} \mathrm{PCy}_{2}\right\}\right]$}

1,2-Bis(dicyclohexylphosphino)ethane $(0.47 \mathrm{~g}, 1.1 \mathrm{mmol})$ in $\mathrm{CH}_{2} \mathrm{Cl}_{2}(5 \mathrm{~mL})$ was added to a stirred solution of $\left[\mathrm{GeF}_{4}(\mathrm{MeCN})_{2}\right]$ $(0.28 \mathrm{~g}, 1.2 \mathrm{mmol})$ in $\mathrm{CH}_{2} \mathrm{Cl}_{2}(10 \mathrm{~mL})$ and the mixture was stirred for $2 \mathrm{~h}$. The solvent was removed in vacuo to give a white solid which was washed with hexane $(10 \mathrm{~mL})$, filtered off and dried in vacuo. Yield $0.43 \mathrm{~g}, 68 \%$. Required for $\mathrm{C}_{26} \mathrm{H}_{48} \mathrm{~F}_{4} \mathrm{GeP}_{2} \cdot \frac{1}{2} \mathrm{CH}_{2} \mathrm{Cl}_{2}$ (613.5): C, 51.8; H, 8.3. Found: C, 52.0; H, 8.5\%. ${ }^{1} \mathrm{H}$ NMR (300 MHz, $\left.\mathrm{CDCl}_{3}, 295 \mathrm{~K}\right): \delta=1.28-2.22\left(\mathrm{~m}, \mathrm{CH}_{2}\right.$ ). IR (Nujol): $592(\mathrm{~s}, \mathrm{vbr}) v(\mathrm{GeF}) \mathrm{cm}^{-1}$.

\section{trans- $\left[\mathrm{GeF}_{4}\left(\mathrm{PMe}_{3}\right)_{2}\right]$}

Trimethylphosphine $(0.152 \mathrm{~g}, 2.0 \mathrm{mmol})$ was added dropwise to a solution of $\left[\mathrm{GeF}_{4}(\mathrm{MeCN})_{2}\right](0.23 \mathrm{~g}, 1.0 \mathrm{mmol})$ in $\mathrm{CH}_{2} \mathrm{Cl}_{2}(10 \mathrm{~mL})$; the mixture was stirred for $2 \mathrm{~h}$. Most of the solvent was removed in vacuo and then filtered to give a white powder which was dried in vacuo. Yield $0.15 \mathrm{~g}, 48 \%$. Required for $\mathrm{C}_{6} \mathrm{H}_{18} \mathrm{~F}_{4} \mathrm{GeP}_{2} \cdot \frac{1}{2} \mathrm{CH}_{2} \mathrm{Cl}_{2}$ (343.5): C, 22.7; H, 5.5. Found: C, 22.7; H, 5.6\%. ${ }^{1} \mathrm{H}$ NMR $\left(300 \mathrm{MHz}, \mathrm{CDCl}_{3}, 295 \mathrm{~K}\right): \delta=1.46(\mathrm{~d}) ;{ }^{2} J_{\mathrm{PH}}=12 \mathrm{~Hz}$. IR (Nujol): 575(s,vbr). Raman: 508(ms) $v(\mathrm{GeF}) \mathrm{cm}^{-1}$.

\section{trans- $\left[\mathrm{GeF}_{4}\left(\mathrm{PPh}_{3}\right)_{2}\right]$}

A solution of triphenylphosphine $(0.52 \mathrm{~g}, 2.0 \mathrm{mmol})$ in $\mathrm{CH}_{2} \mathrm{Cl}_{2}$ $(5 \mathrm{~mL})$ was added dropwise to a solution of $\left[\mathrm{GeF}_{4}(\mathrm{MeCN})_{2}\right]$ $(0.23 \mathrm{~g}, 1.0 \mathrm{mmol})$ in $\mathrm{CH}_{2} \mathrm{Cl}_{2}(10 \mathrm{~mL})$; the mixture was stirred for $3 \mathrm{~h}$. A white precipitate was filtered off and dried in vacuo. Yield $0.60 \mathrm{~g}, 89 \%$. Required for $\mathrm{C}_{36} \mathrm{H}_{30} \mathrm{~F}_{4} \mathrm{GeP}_{2} \cdot \frac{1}{4} \mathrm{CH}_{2} \mathrm{Cl}_{2}$ (694.4): $\mathrm{C}$, 62.7; H, 4.4. Found: C, 63.0; H, 4.4\%. ${ }^{1} \mathrm{H} \mathrm{NMR}\left(300 \mathrm{MHz}, \mathrm{CDCl}_{3}\right.$, $295 \mathrm{~K}): \delta=7.2-7.6(\mathrm{~m})$. IR (Nujol): $607(\mathrm{~s}, \mathrm{vbr}) v(\mathrm{GeF}) \mathrm{cm}^{-1}$.

\section{Reaction of $\mathrm{GeF}_{4}$ with $o-\mathrm{C}_{6} \mathrm{H}_{4}\left(\mathrm{AsMe}_{2}\right)_{2}$}

$o-\mathrm{C}_{6} \mathrm{H}_{4}\left(\mathrm{AsMe}_{2}\right)_{2}(0.29 \mathrm{~g}, 1.0 \mathrm{mmol})$ was added dropwise to a solution of $\left[\mathrm{GeF}_{4}(\mathrm{MeCN})_{2}\right](0.23 \mathrm{~g}, 1.0 \mathrm{mmol})$ in $\mathrm{CH}_{2} \mathrm{Cl}_{2}(10 \mathrm{~mL})$. The mixture was stirred for $2 \mathrm{~h}$. The white precipitate was filtered off and dried in vacuo. Yield $0.15 \mathrm{~g}$. ${ }^{1} \mathrm{H}$ NMR (300 $\mathrm{MHz}, \mathrm{CD}_{2} \mathrm{Cl}_{2}$, $295 \mathrm{~K}): \delta=1.45$ (s, 12H, Me), 7.43-7.56 (m, 4H, $\left.\mathrm{C}_{6} \mathrm{H}_{4}\right) .{ }^{19} \mathrm{~F}\left\{{ }^{1} \mathrm{H}\right\}$ $\operatorname{NMR}\left(\mathrm{CD}_{2} \mathrm{Cl}_{2}, 220 \mathrm{~K}\right): \delta=-77.7(\mathrm{t}),-118.1(\mathrm{t}) ;{ }^{2} J_{\mathrm{FF}}=66 \mathrm{~Hz}$. IR (Nujol): 657(s), 629(m), 613(m), 595(m) $v(\mathrm{GeF}) \mathrm{cm}^{-1}$. Raman: 664(w), 630(s, br), 602(s, br), $v(\mathrm{GeF}) \mathrm{cm}^{-1}$.

\section{Reaction of $\mathrm{GeF}_{4}$ with $\mathrm{AsMe}_{3}$}

$\mathrm{GeF}_{4}$ was bubbled through a stirred solution of trimethylarsine $(0.30 \mathrm{~g}, 2.5 \mathrm{mmol})$ in hexane $(10 \mathrm{~mL})$. A white solid precipitated which was filtered off and dried in vacuo. ${ }^{1} \mathrm{H}$ NMR $(300 \mathrm{MHz}$, $\left.\mathrm{CDCl}_{3}, 295 \mathrm{~K}\right): \delta=1.16$ (s, Me). ${ }^{19} \mathrm{~F}\left\{{ }^{1} \mathrm{H}\right\} \mathrm{NMR}\left(\mathrm{CD}_{2} \mathrm{Cl}_{2}, 220 \mathrm{~K}\right)$ : $\delta=-127.3(\mathrm{t}),-149.8(\mathrm{t}) ;{ }^{2} J_{\mathrm{FF}}=80 \mathrm{~Hz}$. IR (Nujol): 646(s), 635(s), 600(sh) $v(\mathrm{GeF}) \mathrm{cm}^{-1}$. Raman: 642(s), 596(s, br), $v(\mathrm{GeF}) \mathrm{cm}^{-1}$. The same product was isolated from reaction of $\mathrm{AsMe}_{3}$ with $\left[\mathrm{GeF}_{4}(\mathrm{MeCN})_{2}\right]$ in $\mathrm{CH}_{2} \mathrm{Cl}_{2}$ solution.

\section{trans- $\left[\mathrm{GeCl}_{4}\left(\mathrm{AsMe}_{3}\right)_{2}\right]$}

Trimethylarsine $(0.341 \mathrm{~mL}, 3.19 \mathrm{mmol})$ was added to a stirred solution of germanium(IV) chloride $(0.343 \mathrm{~g}, 1.59 \mathrm{mmol})$ in diethyl ether $(10 \mathrm{~mL})$. This was stirred for $2 \mathrm{~d}$ before $5 \mathrm{~mL}$ of solvent was removed in vacuo and a white solid precipitated out. The solid was filtered off and the filtrate was put in a freezer for 5 d. Colourless crystals formed which were identified by a unit cell determination as trans- $\left[\mathrm{GeCl}_{4}\left(\mathrm{AsMe}_{3}\right)_{2}\right] .{ }^{9}$ The crystals and powder were the same spectroscopically. IR (Nujol): $456(\mathrm{~s}) v_{3}\left(\mathrm{GeCl}_{4}\right) \mathrm{cm}^{-1}$. Raman: 266(vs) $\mathrm{a}_{1 \mathrm{~g}}(\mathrm{GeCl}) \mathrm{cm}^{-1}$.

\section{trans-[GeCl$\left.{ }_{4}\left(\mathrm{AsEt}_{3}\right)_{2}\right]$}

Triethylarsine $(0.388 \mathrm{~mL}, 2.76 \mathrm{mmol})$ was added to a stirred solution of germanium(IV) chloride $(0.296 \mathrm{~g}, 1.38 \mathrm{mmol})$ in diethyl ether $(10 \mathrm{~mL})$. This was stirred overnight before $5 \mathrm{~mL}$ of solvent was removed in vacuo and was refrigerated when a white solid precipitated, which was filtered off and dried in vacuo. Yield $45 \%$. Required for $\mathrm{C}_{12} \mathrm{H}_{30} \mathrm{As}_{2} \mathrm{Cl}_{4} \mathrm{Ge}$ (538.6): C, 26.8; H, 5.6. Found: C, 24.3, H 5.5\%. ${ }^{1} \mathrm{H}$ NMR (300 MHz, $\left.\mathrm{CDCl}_{3}, 295 \mathrm{~K}\right): \delta 1.15(\mathrm{t}$, $3 \mathrm{H} \mathrm{CH}_{3}$ ), 1.42 (q, 2H, $\mathrm{CH}_{2}$ ). IR (Nujol): 456(s) $v_{3}\left(\mathrm{GeCl}_{4}\right) \mathrm{cm}^{-1}$. Raman: 259(vs) $\mathrm{a}_{1 \mathrm{~g}}(\mathrm{GeCl}) \mathrm{cm}^{-1}$.

The filtrate was put in a freezer for 5 days before the solvent was removed in vacuo which gave pale yellow crystals identified as $\mathrm{Et}_{3} \mathrm{AsCl}_{2}$ from an $\mathrm{X}$-ray structure determination. ${ }^{1} \mathrm{H} \mathrm{NMR}$ $\left(300 \mathrm{MHz}, \mathrm{CDCl}_{3}, 295 \mathrm{~K}\right): \delta=1.60\left(\mathrm{t},{ }^{3} J_{\mathrm{HH}}=7.5 \mathrm{~Hz}, 9 \mathrm{H}\right.$, Me), 3.06 (q, 6H, $\mathrm{CH}_{2}$ ). Raman: 611(m), 527(vs), 413(m), 338(m), 254(vs) $\mathrm{cm}^{-1}$.

\section{Oxidation reactions of germanium coordinated phosphanes}

A sample of $\left[\mathrm{GeF}_{4}\left\{\mathrm{Ph}_{2} \mathrm{P}\left(\mathrm{CH}_{2}\right)_{2} \mathrm{PPh}_{2}\right\}\right](0.1 \mathrm{~g})$ was dissolved in degassed anhydrous $\mathrm{CH}_{2} \mathrm{Cl}_{2}$ under dinitrogen in a small Schlenk tube and the solution frozen solid at $77 \mathrm{~K}$. The system was evacuated and then filled with ${ }^{18} \mathrm{O}_{2}$ to 1 atm and allowed to warm to room temperature. After 2 weeks a sample was removed for ${ }^{31} \mathrm{P}$ NMR study, and the remaining solution shaken up with $1 \mathrm{M}$ aqueous $\mathrm{NaOH}$. The organic layer was separated, dried 
Table 6 Crystal data and structure refinement details ${ }^{a}$

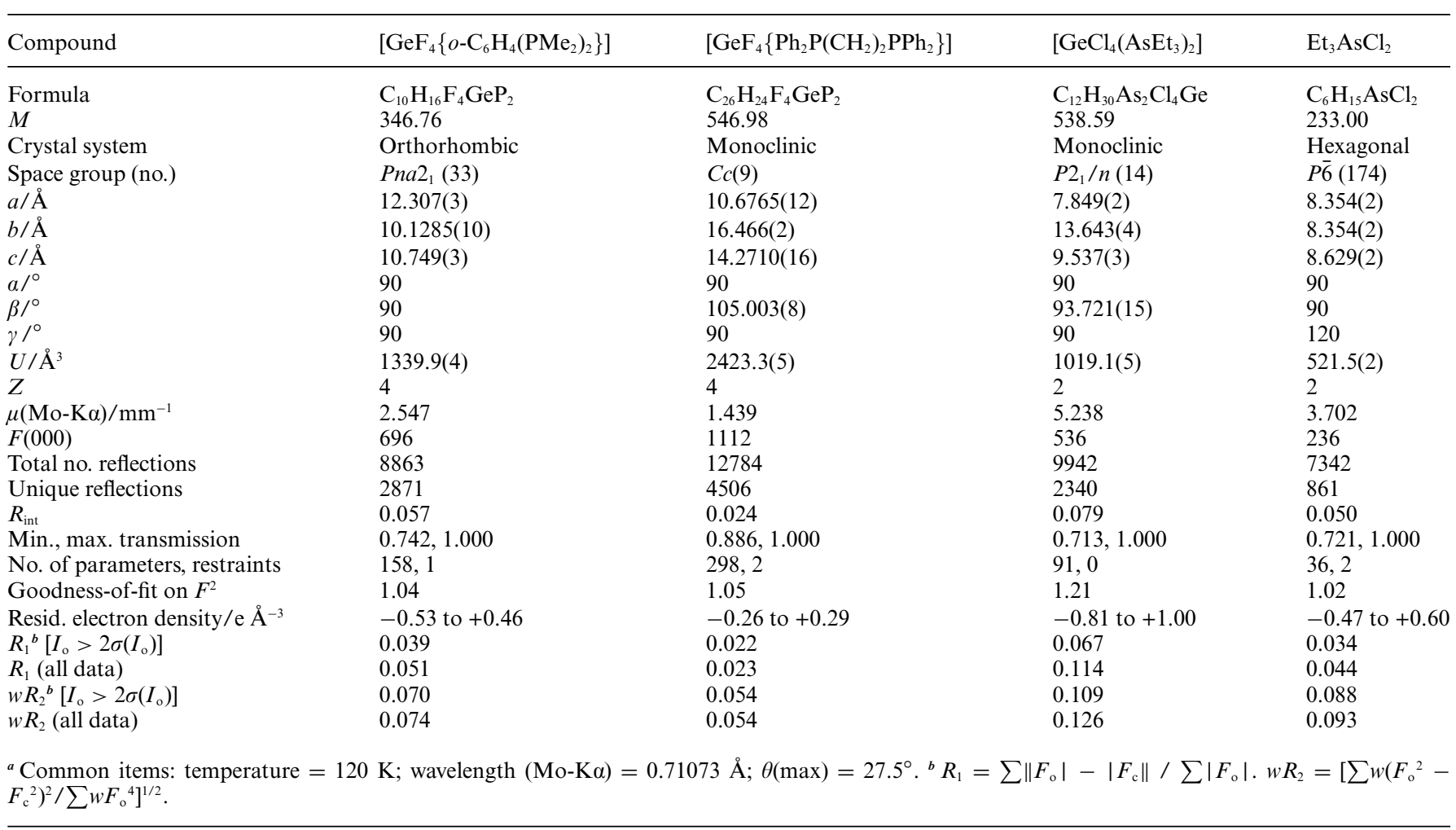

with molecular sieve, and then the solution decanted off and pumped dry. The white solid obtained was used directly for EI mass spectrometry and IR spectroscopy studies (see Results and discussion for spectroscopic data).

\section{The $\mathrm{GeCl}_{4}-\mathrm{PMe}_{3}$ reaction}

In a small Schlenk tube, $\mathrm{GeCl}_{4}(\sim 0.15 \mathrm{~g})$ was distilled in vacuo onto $\mathrm{PMe}_{3}(0.105 \mathrm{~g}, 1.38 \mathrm{mmol})$ at $77 \mathrm{~K}$. The mixture was cautiously allowed to warm and on melting immediately transformed into a white solid. The Schlenk was briefly evacuated to remove any excess reagent and then filled with dry dinitrogen; the Raman spectrum of the solid was recorded without removing it from the Schlenk. The solid was then dissolved in $\mathrm{CH}_{2} \mathrm{Cl}_{2}(20 \mathrm{~mL})$ and the solution allowed to stand for $3 \mathrm{~h}$ and then pumped dry. The solid was identified as $\left[\mathrm{PMe}_{3} \mathrm{Cl}\right]\left[\mathrm{GeCl}_{3}\right]$ (see text for spectroscopic data).

\section{X-Ray crystallography}

Details of the crystallographic data collection and refinement parameters are given in Table 6. Crystals of $\left[\mathrm{GeF}_{4}\left\{o-\mathrm{C}_{6} \mathrm{H}_{4}\left(\mathrm{PMe}_{2}\right)_{2}\right\}\right]$ were obtained from a solution in $\mathrm{CH}_{2} \mathrm{Cl}_{2}-\mathrm{n}$-hexane by slow evaporation; $\left[\mathrm{GeF}_{4}\left\{\mathrm{Ph}_{2} \mathrm{P}\left(\mathrm{CH}_{2}\right)_{2} \mathrm{PPh}_{2}\right\}\right]$ from $\mathrm{CH}_{2} \mathrm{Cl}_{2}$-n-hexane cooled in a freezer; and $\mathrm{Et}_{3} \mathrm{AsCl}_{2}$ and trans-[ $\left[\mathrm{GeCl}_{4}\left(\mathrm{AsEt}_{3}\right)_{2}\right]$ from $\mathrm{Et}_{2} \mathrm{O}$ solution by slow evaporation under dinitrogen. Data collection used a Nonius Kappa CCD diffractometer using graphite or confocal mirror monochromated Mo-K $\alpha \mathrm{X}$-radiation $(\lambda=0.71073 \AA)$. Crystals were held at $120 \mathrm{~K}$ in a nitrogen gas stream. Structure solution and refinement were generally routine, ${ }^{30-33}$ except as described below with hydrogen atoms on $\mathrm{C}$ introduced in calculated positions using the default $\mathrm{C}-\mathrm{H}$ distance.
The data for $\mathrm{Et}_{3} \mathrm{AsCl}_{2}$ was collected as a monoclinic $C$ lattice using the automated software with $\beta$ close to $90^{\circ}$, however inspection of the data with Layer $^{34}$ gave an orthorhombic system as being probable. No satisfactory solution emerged in any of the possible orthorhombic space groups with the initial promising molecules failing to refine. The strategy of trying to solve the structure in $P 1$ was explored and the transformation matrix by good fortune produced a cell that looked remarkably hexagonal. A solution with $Z=2$ in $P 1$ readily followed $(R 1=0.042)$, but with severe correlation problems during refinement. The triclinic coordinates were finally transformed to the correct hexagonal system. The systematic absences for the transformed data gave $0001=2 n$, but it was likely from the As positions that this was not arising from relationships between symmetry related molecules, but rather from the difference in the $z$ coordinates of these two atoms (and the other atoms). The only hexagonal space group that would accommodate the molecular symmetry found in the triclinic model was $P \overline{6}$ (no. 174). This model converged to $R 1=0.034$ with 36 refined parameters compared with 164 parameters in the triclinic model. Chemically the two models are the same, but in crystallographic terms the higher symmetry is preferred. Selected bond lengths and angles are given in Tables 2-5.

CCDC reference numbers 665905-665910.

For crystallographic data in CIF or other electronic format see DOI: $10.1039 / b 716765 b$

\section{Acknowledgements}

We thank the EPSRC (GR/T09613/01) for support and Dr F. Cheng for help in running the Raman spectra. 


\section{References}

1 W. Levason and C. A. McAuliffe, Coord. Chem. Rev., 1976, 19, 173-185. 2 N. C. Norman and N. L. Pickett, Coord. Chem. Rev., 1995, 145, $27-54$.

3 Comprehensive Coordination Chemistry II, ed. J. A. McCleverty and T. J. Meyer, Elsevier, Oxford, 2004, vol. 3.

4 A. R. J. Genge, W. Levason and G. Reid, Inorg. Chim. Acta, 1999, 288, 142-149; N. Bricklebank, S. M. Godfrey, C. A. McAuliffe and R. G. Pritchard, J. Chem. Soc., Chem. Commun., 1994, 695-696; D. Dakternieks, H. Zhu and E. R. T. Tiekink, Main Group Met. Chem., 1994, 17, 519-535; F. Kunnkel and K. Dehnicke, Z. Naturforsch., B: Chem. Sci., 1995, 50, 848-850.

5 M. F. Davis, M. Clarke, W. Levason, G. Reid and M. Webster, Eur. J. Inorg. Chem., 2006, 2773-2782.

6 I. R. Beattie and G. A. Ozin, J. Chem. Soc. A, 1970, 370-377.

7 D. K. Frieson and G. A. Ozin, Can. J. Chem., 1973, 51, 2685-2696; D. K. Frieson and G. A. Ozin, Can. J. Chem., 1973, 51, 2697-2709.

8 W.-W. Du Mont, H.-J. Kroth and H. Schumann, Chem. Ber., 1976, 109, 3017-3024; W.-W. Du Mont, Z. Anorg. Allg. Chem., 1979, 458, 85-88; F. Ruthe, W.-W. Du Mont and P. G. Jones, Chem. Commun., 1997, 1947-1948.

9 S. M. Godfrey, I. Mushtaq and R. G. Pritchard, J. Chem. Soc., Dalton Trans., 1999, 1319-1323.

10 L. Apostolico, M. F. Mahon, K. C. Molloy, R. Binions, C. S. Blackman, C. J. Carmalt and I. P. Parkin, Dalton Trans., 2004, 470-475.

11 F. Cheng, M. F. Davis, A. L. Hector, W. Levason, G. Reid, M. Webster and W. Zhang, Eur. J. Inorg. Chem., 2007, 2488-2495.

12 K. O. Christe, C. J. Schack and R. D. Wilson, Inorg. Chem., 1976, 15, 1275-1282; J. E. Griffiths and D. E. Irish, Inorg. Chem., 1964, 3, $1134-1137$.

13 M. Sigl, A. Schier and H. Schmidbaur, Eur. J. Inorg. Chem., 1998, 203210; F. Cheng, A. L. Hector, W. Levason, G. Reid, M. Webster and W. Zhang, Inorg. Chem., 2007, 46, 7215-7223.

14 F. Cheng, M. F. Davis, A. L. Hector, W. Levason, G. Reid, M. Webster and W. Zhang, Eur. J. Inorg. Chem., 2007, 4897-4905.

15 M. F. Davis, W. Levason, G. Reid, M. Webster and W. Zhang, Dalton Trans., 2008, 533-538.
16 M. F. Davis, W. Levason, G. Reid and M. Webster, Polyhedron, 2006, 25, 930-936.

17 W. Levason, R. Patel and G. Reid, J. Organomet. Chem., 2003, 688, $280-282$.

18 S. M. Godfrey and A. Hinchcliffe, J. Mol. Struct., 2006, 761, 1-5 and references therein.

19 G. Kociok-Köhn, J. G. Winter and A. C. Filippou, Acta Crystallogr., Sect. C, 1999, 55, 351-353.

20 H. E. Blayden and M. Webster, Inorg. Nucl. Chem. Lett., 1970, 6, 703705 .

21 N. N. Greenwood and A. Earnshaw, Chemistry of the Elements, Butterworth, Oxford, 2nd edn, 1997; W. E. Dasent, Non-existent Compounds, Dekker, New York, 1965.

22 L. Verdonck and G. P. Van der Kelen, Spectrochim. Acta, Part A, 1977, 13, 601-606.

23 M. B. Hursthouse and I. A. Steer, J. Organomet. Chem., 1971, 27, C11-12.

24 S. Pascu, L. Silaghi-Dumitrescu, A. J. Blake, W.-S. Li, I. Haiduc and D. B. Sowerby, Acta Crystallogr., Sect. C, 1998, 54, 219-221.

25 K. Nakamoto, Infrared Spectra of Inorganic and Coordination Compounds, Wiley, New York, 2nd edn, 1970.

26 R. D. Feltham, R. S. Nyholm and A. Kasenally, J. Organomet. Chem., 1967, 7, 285-288.

27 H. C. E. McFarlane and W. McFarlane, Polyhedron, 1983, 2, $303-$ 304.

28 A. M. Aguiar and J. Beisler, J. Org. Chem., 1964, 29, 1660-1662.

29 E. P. Kyba, S. T. Liu and R. L. Harris, Organometallics, 1983, 2, $1877-$ 1879.

30 G. M. Sheldrick, SHELXS-97, Program for solution of crystal structures, University of Göttingen, Germany, 1997.

31 G. M. Sheldrick, SHELXL-97, Program for refinement of crystal structures, University of Göttingen, Germany, 1997.

32 G. M. Sheldrick, SADABS, Bruker-Nonius area detector scaling and absorption correction (V2.10), University of Göttingen, Germany, 2003.

33 H. D. Flack, Acta Crystallogr., Sect. A, 1983, 39, 876-881.

34 L. J. Barbour, J. Appl. Crystallogr., 1999, 32, 351. 